\title{
The General Counsel, Gatekeeping, and the Investor Public: Uneasy Bedfellows?
}

\author{
by \\ Mahnam A. Malamiry \\ A thesis submitted to the Law \& Legal Studies department in partial fulfillment of \\ the requirements for the degree of \\ Master of Arts \\ in \\ Legal Studies
}

Carleton University

Ottawa, Ontario

(C) 2013

Mahnam A. Malamiry 


\begin{abstract}
This thesis examines the role of the general counsel across Canadian and American comparisons, specifically with reference to Enron, Livent, and Hollinger cases of fraud. The General Counsel has been within a debate concerning their heightened role for disclosure in the American Sarbanes-Oxley Act. The General Counsel is in a unique position as both a business executive, and a law professional that can mediate their ethical obligations as a professional, as well as their fiduciary obligations as a corporate executive. Two models of responsibility will be examined: that of transaction engineer, and that of gatekeeper. Transaction engineer is primarily situated as a means of maximizing value for the corporation through the general counsel's legal expertise, and this can include "loophole lawyering". In such a context, Counsel may be failing to provide adequate representation for corporate fiduciary responsibilities, as well as their ethical responsibility to not undermine the law in the pursuit of aggressive competitive advantage and short-term profit.
\end{abstract}




\section{Acknowledgements}

This project would certainly not be possible without the excellent help and continued support of Professor Neil Sargent. It has been a pleasure learning from such a great and patient teacher.

My family, friends, and colleagues at Carleton University Legal Studies have been a wonderful source of support both inside and outside the classroom. This process has certainly had its challenges, and it is always such great persons that made the process much more bearable.

The comments and feedback of Professors Alberto Salazar and Lynn Campbell were exceptionally helpful on earlier drafts of this paper, and I thank them very much for their help. Legal research would certainly not be as joyful of a process were it not for all the people who were part of the journey with me. As always, any views, errors, or omissions are my responsibility. 
The General Counsel, Gatekeeping, and the Investor Public: Uneasy Bedfellows?

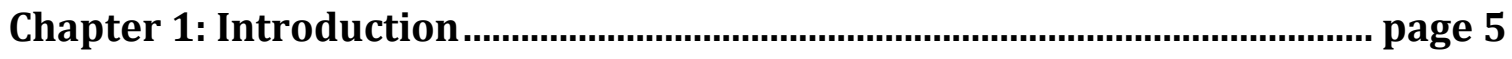

Chapter 2: Corporate agency, law and theory .............................................page 12

Corporate Personality and Agency Theory ................................................................... 14

The Board of directors and corporate oversight ………............................................. 21

The Role of the Audit Committee ................................................................................ 25

The Role of General Counsel as Professional Intermediary ......................................... 29

The corporate lawyer, corporation, and executive: a triangular relationship....................31

Situating the lawyer within the corporation: engaging the innkeeper .................................34

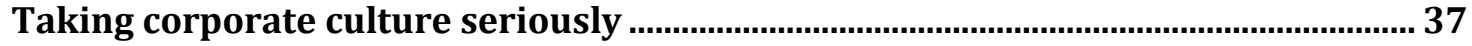

Lawyers and the "triangular relationship" revisited..................................................... 40

The lawyer as gatekeeper.......................................................................................................... 42

Chapter 3: Securities Market Integrity and the Gatekeeper .......................page 46

Informational integrity and the modern securities market ........................................... 46

Professionals, the investor public, and the securities markets................................... 47

Auditing and the certainty of corporate disclosure ..................................................... 48

Investor reliance, professional intermediaries, and the securities market........................49

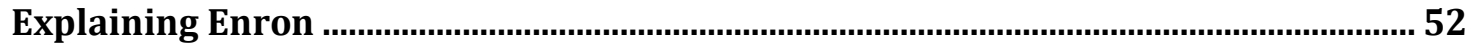

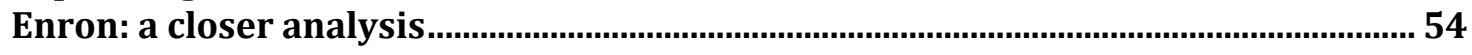

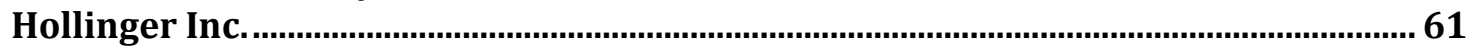

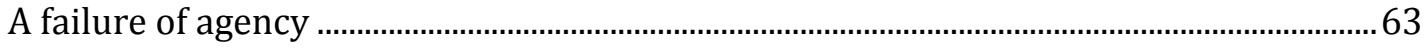

Internal gatekeeper liability and the "ostrich" theory of negligence..................................65

Livent and the Ethical Responsbilities of Internal Corporate professionals ............. 68

Chapter 4: Concluding the Debate .............................................................page 77

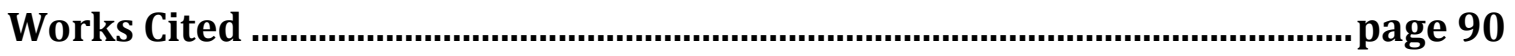




\section{Chapter 1: Introduction}

This thesis was inspired out of a desire to better understand how it is that corporate fraud can occur in sophisticated corporate organizations. Such an understanding looks to both Canadian and American sources of securities and corporate law, so as to better understand and comparatively assess how cases of corporate fraud and misconduct have been addressed. Such an analysis is especially important because of the significant, and unexpected collapse of various corporations and the significant economic harm that it caused within the capital markets. One such case of Enron was once seen as one of the most prestigious and successful corporations in American history. ${ }^{1}$ Hollinger was, for a very long time, a massive media conglomerate that successfully amalgamated various multinational sources for news. ${ }^{2}$ Similarly, Livent was one of Canada's largest and most famous theatre companies. ${ }^{3}$ Yet all these companies were subject to cases of fraud and misconduct that decimated their profit, often leaving the corporations and their various stakeholders with lost financial capital and confidence in the securities markets. When we consider that these various cases of corporate fraud and misconduct occurred in sophisticated corporate organizations, the cases become even more spectacular. Highly trained and experienced executive officers, prestigious members on boards of directors, and specialized auditors, in-house corporate lawyers, and external analysts in the form of underwriters and

1 Grant Kirkpatrick, "The Corporate Governance Lessons from the Financial Crisis" (2009) 2009 OECD Journal: Financial Market Trends 1 at 3. ${ }^{2}$ USA v Conrad M Black, Peter Y Jackson, John A Boultbee, \& Mark S Kipnis, No. 07 4080 (7th Cir 2008) at 1-2 [USA v Black on Appeal].

${ }^{3} R v$ Drabinsky, 242 CCC (3d) 449, 2009 CanLII 12802 (ON SC) at 2. 
investment specialists were often unable to foresee the collapses of these various corporations, and the millions of dollars in lost capital that were involved.

A significant question will concern how the disclosure of securities or corporate risks, called "red flags", were not raised in these various cases before the corporate crimes or misconduct occurred. ${ }^{4}$ Special attention will be made to examine the specific role of in-house lawyers, especially the position of the general counsel, because of their proximity to the executive operations of the corporation, as well as their unique position to be able to influence and inform internal oversight and provide legal counsel. In order to better understand the ethical responsibilities of the general counsel, it is useful to look at the multiple roles that corporate general counsel may play, from that of 'transaction engineer' to 'innkeeper', to that of 'gatekeeper'. While much analysis of the general counsel's role focuses on the transactional dimension of the lawyer's duties, recent scholarship has argued that the unique professional skills and strategic position that the general counsel occupies within the corporation provide a means of facilitating transactions and providing strategic counsel to the board on legal and regulatory issues. ${ }^{5}$ Such a role of the General Counsel can also be seen as a source of specialized skills that are a requisite for a corporation to be listed on a public stock exchange, and secondly, to

\footnotetext{
4 James P Hemmer, "Resignation of Corporate Counsel: Fulfillment or Abdication of Duty: (1987-1988) 39 Hastings LJ 641 at 658.

${ }^{5}$ Omari Scott Simmons and James D Dinnage, "Innkeepers: A Unifying Theory of the In-House Counsel Role" (2011) 41 Seton Hall L Rev 77 at 120 [Simmons \& Dinnage, "Innkeepers"].
} 
facilitate legal risk analysis, ${ }^{6}$ as well as engineering corporate transactions through their unique legal skills and abilities. ${ }^{7}$ From this perspective, the role of the general counsel can be viewed as that of an internal gatekeeper, with responsibilities to both the corporate client as well as to external corporate shareholders whose position outside the structure of management makes them reliant on the quality and reliability of information on legal and financial issues disclosed by corporate management.

Chapter 2 will situate the role of the general counsel within the governance structure of the corporation in order to develop an organizational understanding of how corporate decision-making and oversight occur. Agency theory will be relied upon to provide a means of conceptualizing the delegation of decision-making authority to management agents within the corporation. Special attention will be paid to examining the strengths and limitations of existing forms of corporate oversight, notably between the executive officers, board of directors, and professional gatekeepers both within the corporation, and external to the corporation. Conceptions of information asymmetry, the role of the audit committee, and the scope of the in-house counsel's duties of loyalty and good faith to the corporation will be examined in understanding how corporate oversight occurs. Such an analysis will also take into account the internal organizational

${ }^{6}$ Donald C Langevoort, “Getting (Too) Comfortable: In-House Lawyers, Enterprise Risk and the Financial Crisis (2012) Wis L Rev 495 at 519 [Langevoort, "Getting (Too) Comfortable"]. 7 John C Coffee Jr, Gatekeepers: The Professions and Corporate Governance (New York: Oxford University Press, 2006) at 193 [Coffee, "Gatekeepers"]. 
culture of the corporation, so as to enable a better understanding of the ways in which a culture of competition and a focus on short term profit and aggressive earnings management by senior executives may sometimes pressure professionals within the corporation to passively acquiesce with illegal or fraudulent corporate practices without raising red flags for investors or securities agencies.

Chapter 3 will examine the role of professionals in the communication of financial information to the investor public under securities laws. The impact of mandatory disclosure rules, the dispersion of the investor public, and the inherent reliance by the securities markets on the quality and accuracy of information disclosed by corporation will be examined. The potential for professionals to act as informational intermediaries who add their reputational capital and professional competence to the financial information disclosed by the corporation, will provide a means of better understanding how the securities markets assess the financial information disclosed by corporations. Such information is relevant for risk assessments pertaining to the financial, operational, and legal implications for corporate operations, both in the short and long-term.

It is in this context of the role of professionals in the securities law disclosure process that the "gatekeeping" model will be particularly developed. A gatekeeper is a person who can be seen to be an intermediary between a client and access to a particular market or asset that is in demand, such as being listed on the stock exchange for access to investment capital on the securities markets. An important 
aspect of this role is that the gatekeeper provides a means whereby information can be relied upon as an intermediary with greater certainty by third parties, such as the investor public. An auditor can most readily be seen as an informational intermediary who has a gatekeeping function, because the auditor is a professional whose responsibility it is to verify that information disclosed on the markets is free of material errors. Some scholars, such as John Coffee, have argued that in house corporate counsel can also be seen as a gatekeeper, as they are situated as an intermediary that provides important services to the corporation, and who are also relied by the investor public on the securities market. ${ }^{8}$

The extent to which an in-house legal counsel has any ethical duty to act as a gatekeeper with respect to outside investors and other external stakeholders of the corporation will be considered in chapter 4 . Central to this question is the balance that needs to be drawn between the lawyer's duty of confidentiality to his or her client under the rules of professional conduct, and the demand for increased disclosure and reporting up requirement to protect the interests of the investor public under Canadian and American securities laws.

Recent reforms to the code of professional conduct for lawyers practicing before the Securities Commission in the United States provide a valuable means of assessing a relatively recent change in the ethical responsibilities of in-house

${ }^{8}$ John C Coffee Jr., Understanding Enron: 'It's about the Gatekepeers, Stupid' (Working Paper) (New York: Columbia Law School, 2002), online: http://mba.tuck.dartmouth.edu/mdm/AlumniLearningLinks/CoffeeOnEnron.pdf at 14 [Coffee, "Understanding Enron"]. 
corporate counsel, in response to scandals like the collapse of Enron which led to a re-thinking about the role of internal corporate professionals in facilitating transactions that contributed to the occurrence of corporate scandals that significantly harmed the integrity of the securities markets. Central to this discussion will be an examination of the role of a professional intermediary, such as a lawyer or accountant, as a transaction engineer that passively facilitates services for corporate executives. In comparison to this transaction engineer role, the Sarbanes-Oxley reforms have attempted to enhance the role of in-house corporate counsel and the role of the general counsel as internal gatekeepers, whose responsibility is to actively promote the internal compliance and oversight mechanisms within the corporate governance structure. At present, the rules of professional conduct governing the confidentiality of the lawyer-client relationship in Ontario have not followed the policy shift towards an enhanced model of the inhouse lawyer's gatekeeping responsibilities as far as the Sarbanes-Oxley reforms, ${ }^{9}$ and this chapter will try to assess what the implications of these different approaches to the professional responsibilities of in house counsel as an internal gatekeeper may have within the context of corporate and securities law.

The shift towards a gatekeeper model of the duties of the in-house corporate counsel provides a valuable opportunity to examine the implications that such a

9 Stephanie Ben-Ishai, "Corporate Gatekeeper Liability in Canada" (2007) 42 Tex Int'l LJ 441 at 472 [Ben-Ishai, "Corporate Gatekeeper Liability in Canada"]. As BenIshai states, her "analysis of the academic literature and the comparative context suggest that developing a streamlined approach to amending the gatekeeper liability scheme in Canada, which comes closer to the U.S. and the U.K. models, is not desirable." 
preventive model of legal practice could have for improving corporate governance within the corporation. ${ }^{10}$ Scholars have argued that a culture of overconfidence, excessive risk taking, and a focus on short term profitability on the part of management have often been contributing factors to the creation of conditions within the corporation which resulted in the use of fraudulent or illegal practices to maintain the appearance of corporate profits, and rapid corporate growth, even in the face of deteriorating business conditions or accumulating corporate losses. With this in mind, the thesis also examines three different case studies that exemplify how professionals working with corporations, both internally and externally, contributed to the occurrence of corporate misconduct in such a way that undermined the reliability of information disclosed on the securities markets. The question for further research is whether an enhanced emphasis on the gatekeeping responsibilities of the in-house corporate counsel will be sufficient to enable inhouse counsel to resist such pressures from senior management and avoid adopting a standpoint of passive acquiescence that allows such practices to take place without active intervention or questioning by the corporation's internal or external gatekeepers.

10 Reiner H Kraakman, "Gatekeepers: The Anatomy of a Third-Party Enforcement Strategy" (1986) 2 JL \& Econ 53 at pages 61-62 [Kraakman, "Gatekeepers"]. 


\section{Chapter 2: Corporate agency, law and theory}

This section will first start with a general agency theory of the corporation. Agency theory can provide a valuable means of understanding the governance structure of the corporation, and how oversight, control, and authority are delegated to different groups within the corporation, on behalf of the corporation as an entity. Firstly, we will start with the delegation of authority from the corporation to the board of directors. Next, the relationship of oversight and control between the board of directors and the executive officers of the corporation will be examined. The role of information becomes a critical means of ensuring proper governance and oversight within the corporation. These issues will provide a means of better understanding the role that various professionals play as information intermediaries within the corporation, notably the role that the General Counsel as well as other professionals such as in-house lawyers, and external auditors, have in providing a means for promoting the integrity of the principal-agency relationship in the best interests of the corporation. ${ }^{11}$

Conceptualized broadly, agency theory provides a framework for understanding the expectations and responsibilities of principal and agent in a

11 Coffee, "Gatekeepers”, supra note 7 at 335-36. 
situation of delegated authority. ${ }^{12}$ At its simplest, a principal appoints a particular agent to represent the principal's interests and to act on their behalf. ${ }^{13}$

Where the agent is representing the interests of the principal, it is presumed that any representation made by the agent in the course of his or her duties is not that of the agent acting in their personal capacity, but that of the principal. Thus any representation made by professionals or other agents that are working on behalf of the corporation can in turn incur liability for the corporation. ${ }^{14}$ In such a relationship, the scope of the agent's authority to act on behalf of the principal is determined by the terms of the principal-agent relationship. In some instances the scope of the agent's authority to make representations on behalf of his or her principal may be quite limited. In other cases, the agent may be delegated a considerable amount of discretion to act on behalf of the principal. Regardless of the scope of the agent's authority, a fiduciary duty exists due to the inherent reliance that a particular principal has on the expertise and services that the agent can provide. As such, the agent is under a fiduciary obligation to act with due care, loyalty, and good faith in representing the interests of the principal. ${ }^{15}$ The principalagent relationship becomes more complex within the context of the organizational hierarchy of a corporation, when we take into account the difficulty of

12 Wolfram Muller-Freienfels ,"Law of Agency” (1957) 6 Am J Comp L 165 at 165.

13 Ibid at 169.

14 Reiner H Kraakman, “Corporate Liability Strategies and the Costs of Legal Controls" 93 (1984) Yale L J 857 at 889.

15 Muller-Freienfels, supra note 10 at 169. 
conceptualizing the corporation as an artificial legal person ${ }^{16}$ with its own interests separate from those of its shareholders. ${ }^{17}$

\section{Corporate Personality and Agency Theory}

The modern development of agency law has been seen to grow out of a division of labour after the industrial revolution. ${ }^{18}$ This provides an opportunity to see how agency theory has had to significantly adapt to more modern forms of organization, such as a corporation. Historically, the development of the corporation was seen to be a means whereby group organization could be facilitated, often in public spheres such as churches ${ }^{19}$ and townships ${ }^{20}$. With greater complexity of organizational affairs and divisions of labour, it became much more difficult to assign liability and identity to the persons that would take part in ventures and

16 Arthur R Machen, “Corporate Personality” (1911) 24 Harv Law Rev 253 at 265. 17 John C Coffee, "Beyond the Shut-eyed Sentry: Toward a Theoretical View of Corporate Misconduct and an Effective Legal Response" (1977) 63 Va L R 1099 at 1137 [Coffee, "Shut-eyed Sentry"]. Coffee explains how large complex corporate hierarchies can be problematic:

"the problem of 'authority leakage' are the problems associated with the upward transmission of adverse information within the corporate hierarchy. To the extent that corporate communications are basically serial in nature, so that information is retransmitted from each hierarchical level to the next, the Theory of Cognitive Dissonance suggests one problem. That theory simply states that much-observed phenomenon that recipients of information unconsciously focus on and relay only the information that reinforces their preexisting attitudes, while filtering out conflicting information."

${ }^{18}$ Kathleen M Eisenhardt "Agency Theory: An Assessment and Review" (1989) 14 Acad Manag Rev 57 at 58.

${ }^{19}$ Harold J Laski "The Early History of the Corporation" (1917) 30 Harv L R 561 at 574.

${ }^{20}$ Robert L Raymond "The Genesis of the Corporation" (1906) 19 Harv L R 350 at 356. 
activities within such groups. ${ }^{21}$ As such, there came to be a distinction between the personification of the corporation from the members that would commit their capital and conduct its decision-making authority. This would allow the corporation to have the flexibility to amass capital, and have the decision-making authority to make decisions as a group entity. A result of this corporate framework was that the members who were part of the corporation would have limited liability, because it would be difficult to assign an unlimited level of liability to a particular person's role due to the complexity of group management of the corporation. ${ }^{22}$ This allowed a corporation to continue its identification and status in perpetuity, where it was no longer necessary to re-establish or re-create the identification of a corporation when a new member was changed, or another added on.

This then leaves the corporation in a unique position whereby it is a communal entity, with capital, property, and operational decision-making, made up of various individuals who act on behalf of the corporation. At the same time, however, the corporation is an artificially "created" entity, insofar as it is granted legal rights by the corporate law system. ${ }^{23}$ The very nature of the corporation as a

\footnotetext{
21 Ibid at 354.

${ }^{22}$ Machen, supra note 16 at 265.
}

Machen explains this by showing how "[a]s a corporation is not a rational being, is not capable of understanding law's commands, and has no will which can be affected by threats of legal punishment [...] a corporation is not a person [...] In addressing commands to a corporation, the law can speak only to the human beings who compose it or who manage and control its destinies."

${ }^{23}$ Machen, supra note 16 at 265-66. Therein, Machen elaborates on the artificial nature of the corporation by stating how 
'group' entity placed significant emphasis on the division of labour within the corporation, meaning that it would be unjust to assign liability to one particular member. Rather, liability is assigned predominantly to the corporate entity as a whole. ${ }^{24}$ Thus, where a corporation is bound by contract, such a contractual obligation and any potential liabilities do not extend beyond the immediate personality of the corporation. This means that the shareholders, having committed their property to the corporation, do not lose any more assets than that which has been committed in the form of securities assets. ${ }^{25}$

Agency theory supports this notion of the corporation as a collective entity with its own interests distinct from those of its shareholders. ${ }^{26}$ Since the corporation is an artificial legal entity, it cannot act for itself. Responsibility for managing the affairs of the corporation is thus delegated to the Board of Directors, whose members are elected by a majority vote of the general meeting of shareholders. This delegation of managerial powers by the general meeting to the board is not exhaustive. The general meeting of shareholders of the corporation retains decision-making authority over certain corporate decisions, such as the sale

"Corporations are created, or allowed to be formed, by the state merely for the purpose of benefiting human beings [...] The corporate entity, or personification, which we call a corporation is regarded as having rights and liabilities for the sake of convenience; but it is men of flesh and blood [...] who must in one form or another and in varying degrees enjoy the rights and bear the burdens attributed by the law to the corporate entity."

${ }^{24}$ Laski, supra note 19 at 581.

${ }^{25}$ Michael C Jensen \& William H Meckling, "Theory of the Firm: Managerial Behavior, Agency Costs and Ownership Structure" (1976) 3 J Financ Econ 305 at 341-42.

${ }^{26}$ Raymond, supra note 20 at 354. 
or merger of the corporation, or other fundamental decisions affecting the corporation's operations. ${ }^{27}$

In practice, the board of directors, normally delegates its managerial powers to executive officers of the corporation who are responsible for the day to day running of the corporation's affairs. The senior managers or executive officers in turn report to the board, which retains final authority over the management of the corporation, and over corporate policy, and can, in theory, overrule and discipline executive officers. ${ }^{28}$

The delegation of managerial authority within the corporate organization structure is derived from an expectation that the corporation's agents will exercise their managerial authority in accordance with fiduciary principles, whereby the managers are expected to act at all times in the best interests of the corporation. Having been given a certain amount of trust, the manager as an agent of the corporation has an obligation to represent this trust according to the fiduciary principles of the best interests of the "corporation". ${ }^{29}$ This does not necessarily mean that every action or decision that a senior corporate manager makes must be aimed towards maximizing the short term profitability of the corporation, as there can be a variety of relevant perspectives on what good conduct and managerial

27 Eugene F Fama, “Agency Problems and the Theory of the Firm” (1980) 88 J Polit Econ 288 at 293.

28 Ibid at 293.

${ }^{29}$ Canada Business Corporations Act, RSC 1985, c. C-44, ss. 121, 122 shows fiduciary responsibilities. 
decision-making is at a given time. The common law ${ }^{30}$ does not presume that the interests of the corporation, as an entity, are necessarily identical to those of its shareholders, as there are many other relevant aspects of a corporation, such as business stability, employee, creditor, or social concerns that can be relevant at a given time. ${ }^{31}$ This means that the corporation has various stakeholders with potentially competing interests that are mediated, in a sense, by its elected directors. $^{32}$

The directors and senior managers within the corporation are in a critical position whereby they have a considerable amount of discretion to apply their own business judgment to represent 'the best interests' of the corporation. The business judgment rule has been developed through American common law, ${ }^{33}$ and a similar framework exists in Canadian corporate law. ${ }^{34}$ The directors of the corporation, and, by delegation of authority, the managers that are appointed by the directors, ${ }^{35}$ have

\footnotetext{
${ }^{30}$ BCE v 1976 Debentureholders, 2008 SCC 69, 3 SCR 560 at para 44 shows the fiduciary expectations established by the Supreme Court of Canada of the board of directors. 31 Machen, supra note 16 at 259.

${ }^{32}$ Luh Luh Lan \& Loizos Heracleous, "Rethinking Agency Theory: the View From Law" (2010) 35 Acad Manag Rev 294 at 308.

${ }^{33}$ In re Caremark Inc. Derivative Litigation 1996 Delaware Chancery 698 A.2d 959 was a significant American case that set out the expectations for board of directors oversight; Stephen M Bainbridge, "Caremark and Enterprise Risk Management"(2009) 34 J of Corp Law 968 at 975; Geoffrey P. Miller "A Modest Proposal for Fixing Delaware's Broken Duty of Care" (2010) 1 Colum B L Rev 319 at 322.

${ }^{34}$ Peoples Department Stores, Inc v Wise, [2004] 3 SCR 461, at para 43.

${ }^{35}$ Canada Business Corporations Act, RSC 1985, c. C-44, s. 121 shows the clearly delineated role of such a director within the corporation.
} 
the discretion to make decisions so long as they are justified within the best interests of the corporation.

In an organization that is often very large, bureaucratic, and has multiple managers and executives, with various divisions of expertise and responsibility, there can be different perspectives as to what course of action might be in the best interests of the corporation at any specific point in time. ${ }^{36}$ Thus, it is not unreasonable to presume that there can be a variety of different perspectives on a given issue, and that one idealized, perfect outcome cannot be reasonably anticipated. This is because agency theory recognizes that there is no "perfect representation". There are always information asymmetries in the corporation, whereby an agent has imperfect knowledge and information about the potential outcomes of a given set of decisions and course of conduct ${ }^{37}$ Additionally, the reality of competition between different managerial agents within the corporation and the concept of subgoal pursuits can also be used as a framework for understanding how the actions of a manager as agent may sometimes undermine, or at the level of misconduct or fraud, actively be in conflict with the interests of the corporation as principal. ${ }^{38}$

In their classic study of corporate governance, Berle and Means have attempted to understand how the modern corporation has developed a unique,

${ }^{36}$ Coffee "Beyond the Shut-eyed Sentry", supra note 17 at 1171.

37 Eisenhardt, supra note 18 at 58.

${ }^{38}$ Coffee, "Shut-eyed Sentry" supra note 17 at 1125. 
expert class of managers that govern the corporation's day-to-day affairs. With the expansion of corporate securities markets, the shareholders of the corporation have grown to encompass part-time or passive investors who do not necessarily have the requisite skills, time, nor ability to examine or control the day-to-day affairs of the corporation. ${ }^{39}$ Where in the past, shareholders would have an active role in the governance of corporations, in the selection of a Board of Directors, and oversight of managerial processes, this is no longer necessarily the case. With the dispersion of share ownership, shareholders are no longer as actively involved in the election of Boards of Directors. ${ }^{40}$ This implies that there has become a greater separation between the active involvement of those who manage the firm, that is, the controllers, from those who could be seen to have substantive ownership of the financial capital contributed to the corporation, the shareholders.

This dispersion of shareholder ownership leaves the corporate principal as particularly vulnerable to the good faith of its professional managers. ${ }^{41}$ Corporate executives are specialized experts in the area of corporate managerial decisionmaking and forecasting and have access to information to assess risks and opportunities within the corporation. ${ }^{42}$ Shareholders, by contrast, often lack such professional expertise and access to information. ${ }^{43}$ In response to this concern,

${ }^{39}$ Adolf A Berle \& Gardiner C Means, The Modern Corporation and Private Property (New Jersey: Rutgers Transaction Publishers, 1932) at 279.

40 Ibid at 347.

41 Ibid at $11-12,349$.

42 Ibid at 317-320.

43 Ibid at 322-23. The relationship and inherent dependency of shareholders for information disclosed by the corporation is shown by their example: 
some large institutional investors, such as pension funds, may sometimes seek representation on the board of directors of corporations the funds invest in. But the number of corporations any given large institutional investor may purchase shares in makes this an impractical consideration in many cases.

This particular issue creates a paradox for agency theory, in so far as it can lead to a situation of information asymmetry between the managers as agents and the corporation as principal. ${ }^{44}$ Information asymmetries in turn can result in increased agency costs, as the costs of obtaining access to sufficient information to effectively supervise management increase for the shareholders and the board of directors. ${ }^{45}$

\section{The Board of directors and corporate oversight}

In understanding the role of the board of directors within the corporate governance structure, two issues need to be emphasized. Firstly, this role is one of oversight, whereby the board is responsible for ensuring that management exercises its managerial authority in accordance with legal and business standards. Consequently the board of directors functions more as a monitor than as a manager.

"If, for example, a corporation has decided to double its dividend, there is little, if any excuse for concealing this information for any period of time; the seller, during that period is acting in ignorance of a fact which has not been disclosed to him and which would materially change both his and the market's appraisal if it were known."

${ }^{44}$ Ibid at 134.

45 Donald C Langevoort, "The Behavioural Economics of Corporate Compliance with Law" (2002) 2002 Colum Bus L Rev 71 at 83, 101. 
This oversight function is described by Coffee as being one where "the corporate officer, as agent must pass important policy questions on to his principal, the board of directors." 46 Where senior corporate management is aware of significant potential legal risks affecting the corporation, or a particular manager is known to be in a position of conflict, the potential for breach of fiduciary duty can be avoided by disclosing such risks to the board of directors in advance. An independent committee of the board of directors can then review the issue. ${ }^{47}$ The Board of Directors thus provides oversight of officers' decisions, as well as the potential for pro-actively addressing corporate risks. The flow of information between the Board and management is an essential form of internal oversight and compliance. It has even been conceptualized as the cornerstone of modern corporate governance, where it is a means of promoting regulatory monitoring ${ }^{48}$ and compliance within the corporation and decision-making that is in accordance with conceptions of fiduciary duty, while still maintaining the private, confidential nature of the corporation..$^{49}$

Secondly, the question of director independence is an important one to consider. The independence of the directors is formally expected as a means of providing oversight of the executive officers of the corporation..$^{50}$ This is a means of promoting the agency-principal relationship, so as to ensure that the executive

${ }^{46}$ Coffee, "Beyond the Shut-eyed Sentry", supra note 17 at 1171.

47 Ibid at 1171.

48 Roberta Romano, “The Shareholder Suit: Litigation without Foundation?” (1991)

7 JL Econ \& Org 55 at 55.

${ }^{49}$ Berle \& Means, supra note 38 at 132.

${ }^{50}$ Fama, supra note 27 at 293. 
officers, as the senior agents of the corporation that are in charge of day-to-day operations, are acting according to established fiduciary principles of conduct. ${ }^{51}$

One of the most common critiques of the board of directors is that they are often not truly independent from the executives that they are overseeing. The concern is that where the senior executives have sufficient entrenched authority and power within a corporation, they can exert their influence on the decisions of the board of directors, thus undermining the effective oversight role of the board. A typical instance of this can be seen where the board of directors is comprised of a majority of executive members of the corporation, rather than being more comprised of independent non-executive directors that are external to the corporation. With respect to appointments to the board of directors, the nominating committee of the board may suggest a list of appointments that are, in turn, ratified by the general meeting of shareholders due to a desire to ensure the managerial efficiency of the corporation. This tendency has been especially seen in large corporations with a wide dispersion of shareholders, and where the long-standing CEO has been having continued success in their position. ${ }^{52}$

The risk here is that the role of the directors, as being an independent check and balance on the authority of executive officers result in the directors being reliant on executive authority as a means of setting corporate policy. Should the

${ }^{51}$ Mark S Beasley, Joseph V Carcello, Dana R Hermanson \& Terry L Neal. "The Audit Committee Oversight Process" (2009) 26 Contemp Account Res 65 at 67.

${ }^{52}$ Stuart Rosenstein \& Jeffrey G Watt, "Outside directors, board indepenendence, and shareholder wealth" (1990) 26 JFE 175 at page 177. 
executive officers engage in excessively risky or unlawful corporate behaviour, this can result in such corporate collapses and costs as the cases of Enron ${ }^{53}$ and Hollinger International ${ }^{54}$ have shown. In these two cases, the board of directors was either seen to be significantly passive in their oversight function; 5556 or strategic policy decisions, as well as the day-to-day decision making authority were both under executive officer influence. The result was that where the executives were acting in such a manner that was contrary to the long-term interests of the corporation, the directors were unable to render any control or oversight.

The key point here is that there are various costs associated with legal controls of oversight within a corporation..$^{57}$ Ultimately the Board retains a certain amount of discretion to determine how such mechanisms ought to be established, and according to what reporting and control guidelines. Due to these costs, there can be incentives to promote economic efficiency by reducing oversight controls of management or the corporation generally. The justification for this under an economic perspective of agency law is that the expectation for a higher degree of oversight to protect the interests of a principal results in higher costs. ${ }^{58}$ For example, a higher degree of oversight would result in more transaction costs

${ }^{53}$ Coffee, "Understanding Enron", supra note 8 at 2.

${ }^{54}$ USA v Black on Appeal, supra note 2 at 4 . Conrad Black was seen to have been "acting in his capacity as the CEO of Hollinger when he ordered [general counsel] Kipnis to draft the covenants not to compete and when he duped the [board of directors'] audit committee and submitted a false 10-K."

${ }^{55}$ Coffee, "Understanding Enron", supra note 8 at 2.

${ }^{56}$ USA v Black on Appeal, supra note 2 at 4.

57 Jensen \& Meckling, supra note 25 at 40.

${ }^{58}$ Lan \& Heracleous, supra note 32 at 309. 
associated with screening corporate activities for potential risks to the corporation, as the principal. ${ }^{59}$ Such cost-benefit calculations are central to agency theory, whereby the agent is viewed as a rational economic actor. ${ }^{60}$ Instead of focusing on increasing agency costs, emphasis may be placed on seeking to align the agent's interests with those of the corporate principal. By promoting stock options, a certain fraction of the corporation's future growth is committed to the managerial agent, thus, in theory, providing a means whereby the management would act in their rational self-interest to continue dedicating their good faith to the corporation's continued growth. ${ }^{61}$ Additionally, the fiduciary duty of loyalty and good faith owed to the corporation by its managerial agents may operate as an additional legal incentive towards aligning the agent's interests with those of the corporate principal.

\section{The Role of the Audit Committee}

One of the ways in which the independence of the board of directors from the senior management of the corporation can be improved is through the creation of an audit committee. The audit committee functions as a sub-committee of the board of directors. ${ }^{62}$ Its responsibilities include reviewing the financial statements of the corporation before they are approved by the board of directors and released to the

59 Frank H Easterbrook, "Contract and Fiduciary Duty" (1993) 36 J L \& Econ 425 at 428.

${ }^{60}$ Susan Carle, "Theorizing Agency" (2005) 55 Am U LR 307 at 321.

${ }^{61}$ Jensen \& Meckling, supra note 25 at 45.

62 Beasley, et al, supra note 51 at 67. 
public. ${ }^{63}$ Members of the audit committee are expected to be independent directors, who are not employees of the corporation or otherwise affiliated with the corporation, ${ }^{64}$ and to have some degree of financial literacy. ${ }^{65}$

The audit committee is intended to address the concern about information asymmetry between the executive management and the board of directors, ${ }^{66}$ as well as promoting a general culture of regulatory compliance within the corporation. ${ }^{67} \mathrm{In}$ this way, the audit committee can be seen as a means of filling in a void of internal auditing oversight that provides an additional check or balance over the exercise of managerial discretion in the preparation of the corporation's financial statements. ${ }^{6}$ The audit committee can be seen to function as an internal gatekeeper within the corporate governance structure that is designed to reduce the risk of misconduct or fraud before they result in significant harm to the corporation. ${ }^{69}$ Potential problems can be identified before the external auditors review the financial statements, thus providing a valuable source of internal oversight.

Part of the value of the audit committee is that it plays a more active role than the board of directors in overseeing the financial reporting of the

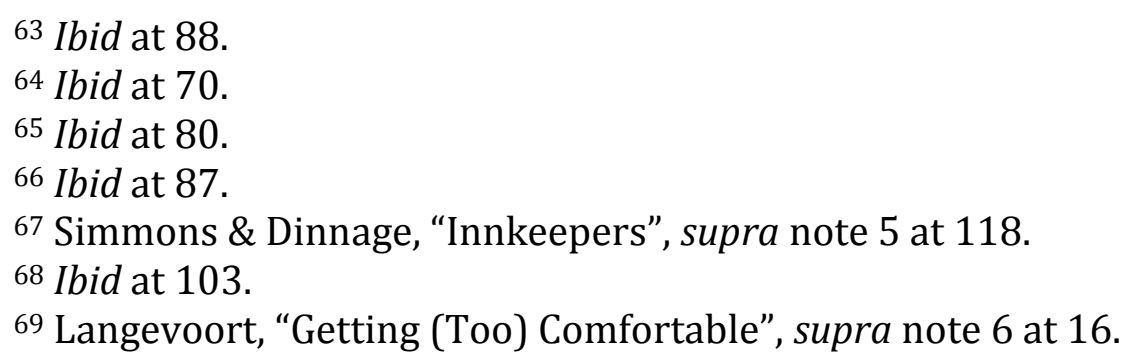


corporation. ${ }^{70}$ However, in practice, this does not change the fact that the members of the audit committee are still likely to be reliant on corporate management as a source of corporate financial information. ${ }^{71}$ Directors, especially non-executive directors, are often part-time, and thus limited in the amount of time they can spend on the corporation's affairs, even as members of the audit committee. ${ }^{72}$ Also, they have less access to internal corporate information than executive officers or senior management, and are thus in less of a position to independently verify information presented to the audit committee by senior management. ${ }^{73}$ Although the audit committee does have the authority to do its own independent financial investigation, it is unlikely this would be utilized unless there is strong evidence of financial irregularities. ${ }^{74}$

Consequently, there is still a potential that the audit committee may be formality that has little substantive ability to prevent opportunities for opportunistic behaviour by corporate management. The case of Livent can be cited as a example of the limits of the audit committee in identifying corporate fraud, where the executive officers were able to manipulate the information disclosed to the audit committee in such a way that the members of the audit committee were

${ }^{70}$ Beasley, et al, supra note 51 at 77.

${ }^{71} \mathrm{Ibid}$ at 95.

72 Coffee, "Gatekeepers", supra note 7 at 7.

${ }^{73}$ Simmons \& Dinnage, supra note 5 at 120.

${ }^{74}$ Beasley, et al, supra note 51 at 95 . As one interviewed audit committee member put it,

"We only discuss [management estimates, judgments, and assumptions] if the external auditor raises this as an issue. The audit committee has a real dependence on the quality of the external auditor and more dependence on the internal auditor." 
unable to assess the material errors that were latent within the financial statements. ${ }^{75}$ There was also the problem that the directors on the audit committee did not have the requisite auditing expertise necessary to be able to understand erroneous financial statements. ${ }^{76}$ Thus, there is a risk that the executive officers may have an incentive to take advantage of information asymmetries between the senior management and the board and the audit committee, as a means of pursuing an aggressive earnings strategy that may represent management's self-interest rather than the interests of the corporation more generally.

$75 R v$ Drabinsky, supra note 3 at para 436. Justice Benotto's analysis is that "The conduct of Mr. Drabinsky and Mr. Gottlieb is [...] consistent with a confidence that nothing would be discovered. The accounting practices at Livent had gone on for a long time. They were entrenched. The financial statements had been audited and presented to the Board of Directors and the Audit Committee. Deloitte \& Touche had gone along with them. The practices had become a way of life and no one had detected them."

76 Beasley, et al, supra note 51 at 93. 


\section{The Role of General Counsel as Professional Intermediary}

This section will examine the role that various professional intermediaries have in contributing to oversight of corporate management, from in-house lawyers, the General Counsel, as well as external professionals such as the corporation's auditors. The concept of professional intermediaries presumes that a professional has a certain degree of expertise and is relied upon for their expertise in a certain area of practice. Reiner Kraakman, one of the initial gatekeeper theorists elaborates how it is the ability of a professional to observe and to recognize misconduct that situates them in a unique position as an intermediary that is distinct from the investors that do not have such access. ${ }^{77}$

One of the significant limitations that agency theory attempts to remedy is that of information asymmetry, where certain members within the corporation have limitations on the information available to them. ${ }^{78}$ In the context of corporate oversight, this means that members of the board of directors are often at a disadvantage as compared with senior management, in terms of their access to

\footnotetext{
77 Kraakman "Gatekeepers", supra note 9 at 99, where he examines the role of underwriters as "informational intermediaries" that provide a unique analysis function of securities assets that are, in turn, relied upon by the investor public. The underwriter commits their reputation to the sale of such assets, and often functions as the primary source of services that promotes the sale of securities to investors on the market.

78 Ibid at 78. Kraakman elaborates that "one of the critical features that distinguishes third-party enforcement in general from direct liability is precisely the uncertainty created by a thirdparty's limited (but unknown) ability to observe misconduct and the latitude enjoyed by third parties and enforcement targets to reshuffle their relationships on the market".
} 
internal corporate information, and are thus reliant on the executive officers or on other professionals within the corporation, to understand the financial performance of the corporation at any given time, or to anticipate the possible consequences of any proposed corporate action. ${ }^{79}$

It is in this context that we can see the role of a professional, such as an inhouse lawyer or general counsel, to be an informational intermediary between the operational side of the corporation and the board of directors. ${ }^{80}$ For example, should there be a case where a particular operation or transaction that an in-house corporate lawyer is working on could be seen to be contrary to the best interests of the corporation, such as in the case of potentially fraudulent conduct or a potential breach of fiduciary duties, there would be an expectation for this lawyer to report up the ladder of authority, if necessary as far as the board of directors. A similar expectation for "reporting up" can be seen with respect to the role of the General Counsel, who reports directly to the Board of Directors pertaining to fiduciary issues. The role of the General Counsel thus becomes a means of providing information and counseling to the board of directors on how to best address the interests of the corporation. ${ }^{81}$

There are certain limitations inherent in this type of "reporting up" expectation. When becoming aware of some level of impropriety or possible illegal

\footnotetext{
${ }^{79}$ Simmons \& Dinnage, "Innkeepers", supra note 5 at 120.

80 Ibid at 116.

81 Ibid at 103, 139.
} 
behaviour, a more junior lawyer may fulfill their obligations by simply reporting to a more senior manager in the corporate hierarchy. The lawyer can then be seen to have discharged their reporting up duty in this regard, and may assume that such a manager or executive would, in turn, report to the board of directors or responsibly address the concern in question. But if the financial misstatement or illegal behavior is in fact condoned by senior management, simply reporting the information up the chain of managerial authority may do little to protect the interests of outside investors or other stakeholders who may suffer losses due to the illegal behavior. By reporting up the managerial chain of authority, the lawyer may avoid any potential risk of civil or criminal liability for being complicit in the offence or the breach of duty; but the action of reporting up the managerial chain may not always be sufficient to ensure the suspected illegal or fraudulent behaviour is prevented or investigated by the corporation.

The corporate lawyer, corporation, and executive: a triangular relationship

It is valuable to define the terms in-house lawyer and the General Counsel. An in-house lawyer is any lawyer that is situated within the corporation, where the only client of the lawyer is the corporation itself. The role of in house counsel is distinct from that of the external law firm, which provides services to the corporation on a contractual basis, in so far as the external law firm may have many clients while the in house corporate counsel is dependent on only one client. ${ }^{82}$ This

82 Ibid at 111-12. 
places the in house corporate counsel in somewhat different position than the 'normal' lawyer-client relationship, as the in house corporate counsel is also an employee of the client, and thus lacks the independence of the external lawyer. ${ }^{83}$ Additionally, the in-house corporate counsel may not formally provide professional legal services to the corporate client in the same manner as an external law firm through paying reduced professional fees as a 'non-practicing lawyer' under law society rules. By being embedded in the corporate governance structure, the in house counsel may thus be called on to play a wider range of 'counseling' duties than an external legal adviser who is contracted to give legal advice on particular issues or transactions. ${ }^{84}$

The general counsel's position is similar to the in-house lawyer, insofar as the general counsel is also trained as a legal professional while often acting in the capacity of a 'non-practicing lawyer'; but differs in that the general counsel is also an executive officer of the corporation. Consequently the general counsel is in a much more influential position of authority within the corporation, and is often a central figure in providing oversight of legal strategies, ${ }^{85}$ compliance, $^{86}$ and the transactional services that are contracted out to external law firms. ${ }^{87}$

\footnotetext{
83 Ibid at 91.

84 Ibid at 99.

85 Susan Hackett, "Corporate Counsel and the Evolution of Practical Ethical Navigation: An Overview of the Changing Dynamics of Professional Responsibility in In-House Practice" (2012) 25 Geo J Legal Ethics 317 at 322. 86 Simmons \& Dinnage, "Innkeepers", supra note 5 at 117

${ }^{87}$ Hackett, supra note 85 at 324 . As she elaborates, "in-house counsel must provide whatever services their clients need. If they can't do the work themselves, then they are responsible for subcontracting that work to outside firms".
} 
The complexity of the principal-agency relationship as it applies to both in house counsel and the corporation's general counsel becomes clear when the question is asked, who exactly is the corporate principal, and whether the principal that exists in theory is the source of influence or evaluation over the agent's professional work in practice. 88

In the context of the in-house lawyer's representative role within the corporate structure, the lawyer's fiduciary duties are owed to the corporation as a legal entity. But as a matter of practice, responsibility for determining what is in the corporation's best interests is normally delegated to the senior management, subject to oversight by the board. ${ }^{89}$ It is management, and especially the executive position of general counsel, that hires the lawyer, and sets rates of compensation for the lawyer. ${ }^{90}$ Moreover, management provides the policy-based assessments and transactional operations that the lawyer applies their services to.

In this regard then, we can see that there is a sort of triangular relationship, as elaborated by Hazard, where the lawyer is representing two sources of authority: the corporate managers whom they are hired by, and work with on a regular basis, as well as the corporation towards which the lawyer owes a duty of loyalty and good

\footnotetext{
88 Hackett, supra note 85 at 320.

89 Simmons \& Dinnage, "Innkeepers", supra note 5 at 114.

90 Ibid at 147.
} 
faith. ${ }^{91}$ Thus, the traditional conception of the principal-agency relationship becomes more complex insofar as there is potentially more than one source of authority that influences the in-house counsel's work in practice. Not only must the lawyer foresee what the interests of the "corporation" as a legal personality at law are, but also take into account the leadership, values, and plans of the executive corporate officers with the ability to hire, evaluate, and fire the lawyer. ${ }^{92}$

\section{Situating the lawyer within the corporation: engaging the innkeeper}

One way of situating the in house counsel within the corporate governance structure of the corporation is to examine the various roles which lawyers can be called upon to play. One such role is to act as what Coffee has called a 'transaction engineer' in facilitating corporate transactions, through the drafting of contracts, completion of business negotiations, and other forms of legal consultation work associated with the practical operations of the corporation. Additionally, in house

91 Geoffrey C Hazard Jr, "Triangular Lawyer Relationships: An Exploratory Analysis" (1988) 68 BUL Rev 1 at 19-22.

92 Langevoort, "Getting (Too) Comfortable", supra note 6 at 25-26: "business risk perception is embedded in legal problems, particularly under the securities and financial services laws. I have made the case for lawyers needing to overcome cognitive biases to do their work well, but it would not surprise me if many CLO's [General Counsel or Chief Legal Officer] turn away from this risk rather than confront it. To the extent that a biased (overly optimistic) view of the company's state of affairs is deeply engrained and embraced throughout the organization, pushing back against it is politically risky, threatening the working relationship between the CEO and the CLO. This is especially so in times when evangelists for risky behaviour have risen to power and may be particularly threatened by dissenting voices. It may be safer from a career perspective to drink the corporate kool aid along with everyone else, even if the legal work suffers as a result." 
corporate counsel may be engaged in what might be referred to as a legal risk management role, evaluating legal and regulatory risks associated with any given aspects of the corporation's business operations. ${ }^{93}$ One of the issues posed by this role, is to what extent the in house counsel should be involved in pro-active legal risk management work, or whether their role tends to be more reactive, evaluating or assessing legal or regulatory risks as these arise in the course of the corporation's operations? Simmonds and Dinnage add a third role, that of providing 'wise counsel' to the board of directors, by acting as an informational intermediary, or "innkeeper" between the executive management and the board. ${ }^{94}$

One study has shown that many corporate general counsel tend to view their role more as transaction engineers, that is, to give advice and planning in the pursuit of transactional planning and legal counsel, rather than on fiduciary concerns that can promote greater transparency and oversight of corporate long-term interests. ${ }^{95}$ Thus, we can see that there are implications for the role of the in house counsel or general counsel between that of the transaction engineer and that of the "wise counselor" pertaining to fiduciary duties. ${ }^{96}$ The role of the lawyer as transaction engineer is primarily focused on enhancing the profitability corporation's bottom line, through facilitating the efficiency of corporate transactions. ${ }^{97}$ By contrast, the

\footnotetext{
93 Simmons \& Dinnage, "Innkeepers", supra note 5 at 105.

94 Ibid at 118-20.

95 Lyman PQ Johnson, “Are Corporate Officers Advised About Fiduciary Duties” (2008-2009) 64 Bus Law 1105 at 1120.

96 Paul D Paton, "Corporate Counsel as Corporate Conscience: Ethics and Integrity in the Post-Enron Era" (2006) 84 Can Bar Rev 533 at 543, 562.

97 Coffee, "Gatekeepers", supra note 6 at 192-93.
} 
legal risk management role, or providing 'wise counsel' to the board on fiduciary responsibilities of executive officers and directors could result in a focus that is not necessarily limited to concerns of cost-reduction for business transactions. Rather, the a more proactive conception of legal risk management and oversight of fiduciary responsibilities within the corporation implies that there can be a shift in thinking towards the longer-term interests of the corporation and its various stakeholders in such a way that is not necessarily limited to transaction cost economics. This means that the reduction of transaction costs is not necessarily the main focus of the general counsel..$^{98}$ Rather, the general counsel can play an important role as an informational intermediary between the board and the corporation's senior management, a role that can assist the board in evaluating the kinds of risks inherent in corporate operations, not only with respect to the reduction of costs, but also with respect to wider stakeholder constituencies such as outside shareholders, employees, creditors, and even government agencies. ${ }^{99}$

The role of the General Counsel as informational intermediary or as 'innkeeper' views the role of the General Counsel to be predominantly that of providing oversight within the corporation. The innkeeper role recognizes the potentially influential position that the general counsel has within the corporation.

As both a lawyer and an executive officer, Counsel has an opportunity to see and influence the organizational culture of the corporation. Moreover, having an

98 John C Coffee Jr "The Attorney as Gatekeeper: an Agenda for the SEC" (2003) 103 Colum L Rev 1293 at 1305.

${ }^{99}$ Stephanie Ben-Ishai "Corporate Gatkeeper Liability in Canada", supra note 9 at 448. 
opportunity to work with the corporate executive means that the general counsel is privy to policies, values, and operational plans that non-executive members of the corporation would not normally have access to. Finally, having a strong understanding of the legal implications of corporate law, governance, and securities law, the general counsel is a unique mix of both a lawyer as well as an executive officer within the corporation. Due to these legal skills and position in senior management, the general counsel is seen by Simmons and Dinnage to be uniquely situated so as to be able to practice preventive law by developing a culture of compliance and legal risk analysis. ${ }^{100}$ This internal form of risk analysis and oversight is intended to complement traditional forms of external gatekeeping roles of professionals, such as the corporation's external auditor, so as to ensure internal systems of compliance are put in place that can promote adherence with corporate law and policy.

\section{Taking corporate culture seriously}

In this context, the work of Donald Langevoort provides a valuable contribution as it provides a framework for understanding how decision-making at different levels in the organization can be affected by corporate culture.101 Corporate culture can be defined as a set of values, norms, or principles that influence the various operations, pursuits, goals, and relationships within the

100 Simmons \& Dinnage, "Innkeepers", supra note 5 at 129-34.

${ }^{101}$ Donald C Langevoort, "Chasing the Greased Pig down Wall Street: A Gatekeeper's Guide to the Psychology, Culture, and Ethics of Financial Risk Taking” (2011) 96 Cornell L Rev 1209 at 1229. 
corporation. ${ }^{102}$ These values are often internalized by virtue of norms that can be found across the business world more generally, such as values of competition and a desire to maintain an appearance of profitability, stability, and competitive returns on investments. ${ }^{103}$ More specifically within the corporation, executive officers are seen to have a significant amount of influence and authority when it comes to defining what norms and values are articulated and prioritized within the corporation. ${ }^{104}$ It is also the executive management of the corporation that appoints key oversight professionals, ${ }^{105}$ such as the General Counsel, recommends the external auditor, and has the authority to hire, promote, or fire less senior nonexecutive managers or officers of the corporation. ${ }^{106}$ Herein then we can see the significant influence of the corporation's senior executive officers in establishing the internal corporate culture within the organization, thus also affecting the ways in which operational goals and values are perceived by managers at all levels within the corporation

From the perspective of agency theory, one of the significant concerns with the impact of corporate culture within the principal-agent relationship is in

102 Ibid at $1217,1233,1240$.

103 Donald C Langevoort "The Organizational Psychology of Hyper-Competition: Corporate Irresponsibility and the Lessons of Enron" (2002) 70 Geo Wash L Rev 968 at 974 [Langevoort, "Hyper-Competition"].

${ }^{104}$ Lyman, supra note 95 at 1120.

105 Eugene A Imhoff Jr, "Accounting Quality, Auditing, and Corporate Governance" (2003) Accounting Horizons 117 at page 121.

${ }^{106}$ Coffee "Gatekeepers", supra note 6 at 335. As Coffee explains, "[e]xcept in very special circumstances, corporate officers hire the attorneys, investment bankers, and other consultants who in turn advise shareholders [...] this raises the prospect that the advice and opinions so given may be biased in favour of management." 
determining when, and to what extent, there is a risk that the interests of the principal will not be adequately represented by the executive officers, as agents in charge of the day-to-day corporate operations. Langevoort's research suggests there is often a highly competitive culture among executive officers in many corporations in the market.107 This culture of "ultra-competition" is such that there can result a deterioration of the agency relationship between the corporation's executive management, lower level managers, and the corporation as principal. ${ }^{108}$ Langevoort argues that there can often be such competitive pressures for immediate profit that this produces an incentive for the exaggeration or manipulation of earnings so as to promote an appearance of profitability, even where there may be a downturn in business conditions. ${ }^{109}$ Moreover, the risk that the corporation's share price may drop if continued growth is not exhibited may add increased pressures on managers to misrepresent the corporation's earnings statements that are disclosed to the investor public, so as to enable continued access to financial capital. ${ }^{110}$ An

${ }^{107}$ Langevoort, "Hyper-Competition", supra note 95 at 970. Langevoort elaborates on how the most successful executives within corporation can be seen to often exhibit traits that "are most ambitious, hard-working, persistent [...] This kind of person needs to be adept at rationalizing a shift of loyalties as conditions dictate [...] is Machiavellian [...] this label connotes deliberate cunning and opportunism [...] It is the behaviour, not the state of mind, that is important [...] there is a second label that I like: ethical plasticity [...] successful executives have an ability [...] to construe what is self-serving to be reasonable, so that moral anxiety is buffered."

108 Coffee, "Gatekeepers", supra note 7 at 336.

${ }^{109}$ Langevoort, "Getting (Too) Comfortable", supra note 5 at 4.

110 Langevoort, "Hyper-Competition", supra note 95 at 972 . Such a source of capital allows the corporation to leverage increased resources in a given market:

"As Enron shows, a high stock price has an independent competitive purpose it provides an acquisition currency and a source of collateral that can be used 
incentive-based system within corporations that attempts to promote corporate growth through stock options and bonuses ${ }^{111}$ may perpetuate an excessively competitive focus on short-term profit, rather than long-term stability. ${ }^{112}$ The problem is that other stakeholders in the corporation may be put at greater risk of corporate mismanagement or fraud due to an overemphasis on aggressive risk taking on the part of senior managers that becomes part of the organizational culture of the corporation, and may influence the expectations of other professionals in the corporate governance structure.

\section{Lawyers and the "triangular relationship" revisited}

This type of problematic relationship can be seen in the "triangular relationship" between the corporation, its senior management, and the general counsel as discussed by Hazard. In this context, we can see the general counsel as being situated in a position where they are responsible to two principals, in a sense: the corporation, as well as the executive officer that has appointed them. ${ }^{113}$ In theory, corporate law recognizes that the general counsel owes a formal duty of loyalty and good faith to the corporation. The fundamental premise of such a duty of

to facilitate substantial (often hidden) leveraging. To a growth-oriented firm, this is crucially important."

${ }^{111}$ Simmons \& Dinnage, "Innkeepers", supra note 5 at 147.

112 William W Bratton, "Enron and the Dark Side of Shareholder Value" (2002) 76 Tul L Rev 1275 at 1293.

113 Hazard, supra note 91 at 16 . The interesting aspect of this framework is that the corporation, as an entity, is dependent on representations between the corporation and the executive officer. Similarly, there is a representative relationship between the general counsel and the executive officers, who often work together to represent the corporation. 
loyalty and good faith is that the General Counsel is an agent on behalf of the corporation, and as such has a duty of care and good faith to not unduly violate corporate interests. ${ }^{114}$ However, in practice, a significant cultural influence is derived from the close relationship with the executive officers of the corporation with whom the general counsel works on a regular basis. Moreover, the General Counsel's role is such that they advise on operational matters that may arise as a consequence of strategic goals that have already been established by senior management. These kinds of factors may help to explain how it is that the general counsel may sometimes fail to raise red flags when it comes to instances of misconduct or fraud.

The problem may be that the role of the general counsel as a professional intermediary is such that they are so aligned with the interests and influence of the executive officers of the corporation that it is difficult to differentiate between the interests of such officers and that of the corporate entity as a principal. It may also be that giving advice to the board on fiduciary matters and providing 'wise counsel' is simply a secondary goal or priority when it comes as compared with more immediately concern with legal risk management and planning for corporate transactions. The important point here is that the formal, theoretical agency relationship between the General Counsel as agent and corporate entity as principal may be so influenced by the internal corporate culture established by senior management that this can help explain how it is that various forms of misconduct

114 Simmons \& Dinnage, “Innkeepers”, supra note 5 at 91. 
and fraud have often remained undetected within corporations until it was too late. The harm being done, as exhibited in various cases such as the Enron and Livent case studies to be examined in the next chapter, has frequently resulted in outright bankruptcy and significant losses for various corporate stakeholders. It is in this context that it is important to consider the implications of a gatekeeping conception of the in house counsel's responsibilities

\section{The lawyer as gatekeeper}

A model of the professional as gatekeeper views the inherent potential that the professional representing a corporation can be "captured", in a sense, by the corporate culture within the corporation. This is especially true in the context of the role of the general counsel, where the general counsel is working very closely with the executive officers of a corporation. One of the means that an ultra-competitive corporate culture can be addressed is to regard the fiduciary obligations of the legal professionals from a more comprehensive, stakeholder-based view of the corporation, that also takes into account the interests of the investor public that rely on such professionals for their services as reputational intermediaries. In this regard, the role of the general counsel, as an informational intermediary can be seen to apply not only to the relationship between senior management and the board of directors, but also to the investor public that relies on the accuracy and reliability of financial information disclosed by the corporation. 
When investors are examining a prospectus prepared by the general counsel, or when investors are examining the financial statements of a corporation that may include representations as to legal or regulatory risks affecting the corporation, there is an appearance of greater certainty as to the trustworthiness in the information disclosed by the corporation. ${ }^{115}$ The status of the General Counsel as a lawyer results in a perception that they can be relied upon as reputational intermediaries. This role of reputational intermediary is similar to that of the corporation's external auditor. The general counsel's role is thus different from that of an external lawyer who provides advice to the corporation on particular legal issues, because the external lawyer is not engaged in making representations to the public, or providing reputational capital to the corporation in its dealings with the investor public.

Because of his or her professional training as a lawyer the general counsel is in a situation that they have the requisite ability to understand the legal implications of corporate conduct better than other members of the executive management. The in-house lawyer is thus in a position that they have the ability, due to their position within the corporation, to have access to information that non-lawyers would not be able to appreciate to the same extent. From the perspective of a deterioration of agency theory due to the in-house lawyer or general counsel being too closely aligned with senior corporate management, a conception of the lawyer's ethical responsibilities that extends beyond the corporate executive suite can be potentially

115 Coffee “Gatekeepers", supra note 6 at 2. 
valuable as a means of providing more effective representation of outside stakeholder interests.

The interests of the investor public here can be interpreted here to mean such values as integrity of earnings disclosure and stability of corporate operations. The recent market collapses have shown that the over-exuberance of corporate executives can result in earnings disclosures being manipulated so as to promote an appearance of profitability. Moreover, an emphasis on short-term profit can be the unintended consequence of efforts to align management's interests with those of shareholders by increasing the percentage of executive compensation that is tied to the corporation's stock market performance. The experience of recent corporate collapses such as Enron and Livent demonstrates that the efficiency of the market can be undermined when there is a tendency on the part of corporate executives to overemphasize short term profit at the expense of long term stability.

While in many instances of corporate fraud and misconduct, the general counsel did not intend to condone violations of the law, the subsequent implications of those situated within the corporation having failed to raise red flags concerning corporate misconduct and earnings manipulations led to catastrophic costs for stakeholders vested in the corporation. By positioning the in-house lawyer or general counsel as a gatekeeper, such a professional has increased ethical responsibilities to a wider investor public, that is, those investors who, because of their lack of direct involvement in the management of the corporation, are forced to 
rely on the quality and accuracy of the financial information disclosed by the corporation. This view of the in-house counsel's role as professional gatekeepers is justified by virtue of an understanding that the in-house counsel's services, in a securities market, are relied upon not only by the corporate entity that has hired them, but also that their services are integral for the sale of securities assets on the markets at large. A closer examination of securities law and policy can provide a more effective understanding of how corporate disclosure relates to the interests of the investor public 


\section{Chapter 3: Securities Market Integrity and the Gatekeeper}

\section{Informational integrity and the modern securities market}

This section will look at the role of securities law in Canadian and American practice. The central aspect that will be examined is the role of information disclosed on the securities markets, as required through mandatory disclosure rules and facilitated by various professional intermediaries. One of the fundamental justifications for the disclosure of information is that improvements in the quality of such information, in the form of "full, true, and plain" disclosure, can serve to promote the efficiency of the securities markets, as well as investor confidence, two fundamental principles for the governance of the securities markets. ${ }^{116} \mathrm{~A}$ fundamental requirement for rational investment decision-making is for there to be accurate, timely, and accessible information concerning securities assets and the corporations that issue such assets.

Information disclosed to the securities markets may come from a number of sources. These can be from the media, through corporate press releases, or analysts reports, or financial coverage in the financial press, to more formal disclosure mechanisms, such as the initial public offering prospectus, or the continuing disclosure requirements of federal or provincial securities laws. The relevant idea of

116 Janis Sarra, "Modernizing Disclosure in Canadian Securities Law: An Assessment of Recent Developments in Canada and Selected Jurisdictions" Commissioned by the Task Force to Modernize Securities Legislation in Canada (2006) at 13 
'risk' here is fundamental, insofar as mandatory disclosure provides a means of disseminating information from the corporation, to the investor public, so as to allow investors to be able to make sound investment decisions concerning whether they wish to purchase shares from a corporation. ${ }^{117}$ The role of professionals as an intermediary can be seen in the disclosure process, as well as the facilitation of transactions between corporations and investors through the securities market.

\section{Professionals, the investor public, and the securities markets}

The analysis provided by professionals can be especially valuable as a means providing an opportunity for the investor public to rely on expertise and authority that would otherwise be unavailable. Moreover, such professionals often have an ability to analyze information in a way that the investor public would be unable to do. This means that professionals, as repeat players on the market, have developed a significant amount of reputational capital that investors rely on in making investment decisions. ${ }^{118}$ The high price that corporations are willing to pay such professionals is testament to the fact that having such a reputational authority behind their assets will mean that more of the investor public will trust their assets. ${ }^{119}$ Such analysis can take the form of verifying the corporation's financial statement, which is the role of the auditor, or analyzing the corporation's future earnings prospects, which is often done by securities analysts, or providing credit

117 Ibid at 882.

118 Coffee "Gatekeepers", supra note 6 at 2.

119 Sarra, supra note 116 at 42. 
rating information on the corporation's debt. Much of this analysis by professional intermediaries can be seen to take the form of risk analysis, as a means of attempting to see the implications for corporate transactions, conduct, and planning as a means of assessing the potential performance of a company's securities assets on the markets. ${ }^{120}$ Thus, we can see that at most stages of the mandatory disclosure process, professionals are present, either as initial consultants, to transaction engineers, and analysts that examine a corporation's securities offering after the actual listing on the markets. In all these instances, the fundamental ability for the investor public and securities markets to be informed relies on the quality of information disclosed by the corporations.

\section{Auditing and the certainty of corporate disclosure}

The auditing function has been purposely developed as a means of ensuring that shareholders of the corporation who are not directly able to supervise corporate operations are able to rely on an auditor as an independent professional to examine the corporation's financial records to ensure that they are free of material errors or misrepresentations. ${ }^{121}$ When we take into account that agency theory recognizes how there can be information asymmetry between shareholders and managers within the corporation, the auditor becomes a valuable opportunity for members of the corporation, such as shareholders, or prospective investors in the markets, to be able to have a more certain understanding of the performance,

\footnotetext{
120 Ibid at 37.

${ }^{121}$ Coffee "Gatekeepers", supra note 6 at 146.
} 
financial liabilities, and various measures of corporate performance that is in addition to the statements made by corporate managers. An explicit aspect of the role of the auditor is that this professional is independent of management, that they are situated external to the corporation purposely to ensure that they are not under the influence of management or corporate culture.122 In addition to the principles of governance established by Canadian corporate law, there are also the Generally Accepted Auditing Standards (GAAS) that provide a set of principles, expectations, and regulations for auditing practices. ${ }^{123}$ In this way, the integrity of the agency relationship is improved insofar as the auditors are able to promote more accurate information transfer pertaining to the status of corporate operations from within the corporation to members that are not privy to such operations.

Investor reliance, professional intermediaries, and the securities market

The promotion of auditor reliance has been seen to develop in congruence with the growth of the securities markets. As more investors need to examine the assets and risks of a corporation, there was an increased demand for an auditor to provide an examination of corporate statements. ${ }^{124}$ These investors would not have the requisite specialized skill and ability to understand the representations that a corporation makes. Moreover, the financial statements and representations would

122 Canada Business Corporations Act, RSC 1985, c. C-44 at s. 168(7)

123 Eugene A Imhoff Jr "Accounting Quality, Auditing and Corporate Governance" (2003) Accounting Horizons 117 at 118.

124 Ross L Watts and Jerold L Zimmerman "Agency Problems, Auditing, and the Theory of the Firm: Some Evidence” (1983) 26 JL \& Econ 613 at 626. 
also be in such a condition that the average investor would not be able to understand the projected possibilities of a given corporation, nor be able to conceptualize whether, and to what extent, there were any material errors or misrepresentations made by the corporation.

Berle and Means point out that as corporations have become more complex and sophisticated there has become a more distinct separation between the expert managers of the corporation, and those who dedicate their capital to the corporation, such as the investors. ${ }^{125}$ With the dispersion of shareholders, control over the corporation as a matter of organizational practice has become increasingly concentrated in the hands of senior management, rather than in the hands of the shareholders, who are in legal terms the owners of the corporation. ${ }^{126}$ Moreover, in a securities market that has grown significantly, there are more "amateur" investors who do not have the ability to necessarily understand how corporations are managed, nor do they necessarily understand the often-complex financial processes that are utilized within corporations. ${ }^{127}$ Lastly, with the development of the

125 Poonam Puri \& Stephanie Ben-Ishai "Proportionate Liability Under the CBCA in the Context of Recent Corporate Governance Reform: Canadian Auditors in the Wrong Place at the Wrong Time?" (2003) 39 Can Bus LJ 36 at 39. As they elaborate, "Berle and Means' conclusions and concerns about the separation of ownership and control in large publicly held corporations are as relevant today as they were in 1932. The separation of ownership and control causes concerns that managers will act in their own interests rather than in the best interests of shareholders. In order to reduce the divergence of interests between those who control (managers) and those who own (shareholders), an array of legal rules and market mechanisms are employed."

${ }^{126}$ Berle \& Means, supra note 38 at 4.

127 Robert M Bushman and Abbie J Smith "Transparency, Financial Accounting Information, and Corporate Governance" (2003) 9 Economic Policy Review 65 at 65. 
securities markets, this has led to a vulnerability, whereby the investor public has grown to such a size that there are many more persons, institutions, firms, and banks involved, that do not necessarily have the ability to oversee the management of corporations, and rely instead on professionals to ascertain the financial viability and status of a corporation.

The development of professional bodies for certifying the qualifications of financial auditors and establishing professional accounting standards enabled the reputational capital of an auditor to be adequately assessed, thus giving a further form of certainty for investors and corporations to be able to assess and verify the quality of auditing services provided at a given time. ${ }^{128}$ Moreover, this has given increased incentive for auditors to ensure that they are providing capable and reliable services to the investing public since otherwise their reputational capital may be negatively impacted by being associated with misleading, unreliable, or wrongful auditing services. Coffee points out that this is a key element of gatekeeping theory as it relates to the role of the auditor, that the cost in terms of loss of reputational capital to the auditor is likely to exceed the benefits to be gained through participating in a fraudulent or misleading earnings statement. ${ }^{129}$ This is what happened in the case of Enron, when the accounting firm associated most closely with Enron's collapse suffered such a loss of reputational capital that the

128 Susan P Shapiro, "Agency Theory" (2005) 31 Annu Rev Sociol 263 at 276.

${ }^{129}$ Coffee, "Understanding Enron”, supra note 8 at 18. 
firm went into bankruptcy, notwithstanding that it had been one of the top five accounting firms in the United States. ${ }^{130}$

Research into situations of gatekeeper failure suggests that the reputational capital of the auditor in certifying the corporation's financial statements thus depends on the auditor's independence from management, as well as the auditor's professional competence. Where the independence of the auditor as an informational intermediary is compromised, the risks of corporate fraud and earnings misstatements is likely to increase, resulting in financial losses for investors. This situation was very relevant in the collapse of Enron, where even large professional investors, such as state and municipal pension funds, ${ }^{131}$ were not able to ascertain the misleading nature of Enron's financial statements because the very professionals that were relied upon as intermediaries between the corporation and the markets, such as law and accounting firms, did not disclose information pertaining to the risks of aggressive Enron financial schemes. ${ }^{132}$

\section{Explaining Enron}

John Coffee states that there are three complementary theories as to why Enron's fraudulent scheme reached such massive proportions without having been detected by corporate governance agencies, such as the US Securities and Exchange

130 Ibid at 7-8.

131 Coffee, "Gatekeepers", supra note 7 at 22.

132 Bratton, supra note 112 at 1304. 
Commission. Firstly, that gatekeeper regulation may have weakened, resulting in a decline in threat to gatekeepers, that is, for lawyers, accountants, and financial professionals to be held liable through private litigation and SEC enforcement. As a result of this, there is greater incentive for gatekeepers to acquiesce to managerial pressure, and inflate corporate profits. ${ }^{133}$ Second, the emphasis on short-term profit can also be part of the reason why corporate profits can be inflated, and costs or losses hidden, so as to promote an appearance of profitability for the corporation's stock value, and in turn the value of management's compensation in the form of stock options. ${ }^{134}$ As such, management would have greater incentive to pressure or incentivize gatekeepers to take on riskier accounting practices. The third hypothesis is that of the "stock market bubble": that investors become accustomed to progressive increments of stock prices and profit, and thus are not as skeptical of corporate ventures. Coffee elaborates that

"[i]n this atmosphere of market euphoria, gatekeepers become irrelevant - or, even worse, shareholders reinforce the pressure on them for the use of risky or improper accounting policies in order to sustain hyperbolic earnings growth. Caught between the pressure of managers and stockholders for constantly increasing profits, auditors and analysts may learn to tell their audience what they want to hear."135

Thus there is the potential that corporate markets generally are trapped in a pattern of "market euphoria", of expectations of continued profit, with little skepticism due to such market normative trends, thus increasing the self-fulfilling prophecy that corporate ventures will indeed continue to be profitable, regardless

133 Coffee, "Understanding Enron", supra note 8 at 13-14.

134 Coffee "Gatekeepers", supra note 6 at 55.

135 Ibid at 56. 
of their operational management. Most interesting with this theme is that Enron was not an anomaly in terms of risky, aggressive accounting reporting practices and manipulation of financial statements. Enron's bankruptcy in 2001 was part of a wider tendency in the early 2000s of "behavioral changes and increased risk-taking at large, mature firms." 136 With greater emphasis on risk-taking to serve short-term profit and an increased appearance of stability, there is often a tendency for corporate management, which ultimately has the discretion to hire, fire, and appoint in-house lawyers, accountants, as well as external auditing firms, to pressure them to maintain profit-based priorities.

\section{Enron: a closer analysis}

The Enron case provides a valuable opportunity for analysis because of the significance it provided for the development of the regulatory conception of gatekeeping in practice. Prior to going into bankruptcy, Enron had at one point been the seventh largest corporation by stock market valuation listed on the New York Stock Exchange. ${ }^{137}$ Investigations into the cause of the corporate failure identified a number of factors, which included complex transactions involving subsidiary corporations and limited partnerships owned by the corporation's chief financial officer, which were intended to remove debts from the corporation's balance sheet, and make it appear that corporation was far more profitable than it actually was. ${ }^{138}$

136 Ibid at 58.

137 Bratton, supra note 112 at 1276.

138 Ibid at 1306. 
The management of Enron was very hierarchical and decentralized, a trait that can occur among the bureaucratic organization structure of large public corporations. We have the senior executives, of various disciplinary specializations, such as finance, operations, general counsel, accounting, that each have their area of authority delegated to them. ${ }^{139}$ The difficulty herein comes from how risk is analyzed and understood at the organizational level. A significant concern is that risk, especially financial or legal risk, cannot be readily, and transparently, evaluated within a large hierarchically structured corporation.

This is why the role of professionals as information intermediaries is so critical to an understanding of such corporate failures. In house counsel provide the capacity for assessment of legal risk analysis within the corporation, and informing the board of their legal risk analysis of any given corporate course of conduct.140 Auditors have a similar function in relation to the corporation's audited financial statements. If the professional intermediaries such as auditors and in-house counsel are actively engaged in the design and implementation of such risky or overly aggressive financial strategies, ${ }^{141}$ they are likely to fail in their gatekeeping duties towards the outside investors markets and other stakeholders in the corporation. ${ }^{142}$

${ }^{139}$ Coffee, "Beyond the Shut-eyed Sentry", supra note 17 at 1139.

${ }^{140}$ Simmons \& Dinnage, "Innkeepers", supra note 5 at 112.

${ }^{141}$ Langevoort, "Getting (Too) Comfortable", supra note 6 at 22.

${ }^{142}$ Coffee, "It's about the Gatekepers", supra note 6 at 11-14. 
The external certification of Enron's financial statements was done by Andersen Accounting, a full service accounting firm that would externally audit Enron, as well as provide consulting services. Enron had virtually become the only client of Andersen, and as such, exerted significant influence on Andersen's auditing function, by virtue of the significant profit that Andersen would derive by providing consulting services. Evidence shows that Andersen had accumulated upwards of $\$ 100$ million in fees from Enron, ${ }^{143}$ most of which came from their consulting, rather than auditing, services. ${ }^{144}$ Additionally, one of Andersen's leading accountants had been appointed as Enron's Chief Accounting Officer, ${ }^{145}$ thus clearly establishing a connection between Enron's executive management and its external auditor. Subsequently, the executive management of Enron was able to exert pressure on Andersen Accounting to certify disclosure statements that were misleading and omitted information concerning the true nature of Enron's financial circumstances.

Enron is a prime example of how the corporation's executive officers had worked in conjunction with the in-house corporate counsel to develop and implement a scheme that utilized the certification and verification function of accountants as a means of legitimizing the financial accounting scheme to mislead the investor public and securities commission. ${ }^{146}$ As a result of this, Andersen's verification function as a gatekeeper, was flawed: it had a clear incentive to allow Enron's financial manipulations to go unnoticed, so as to continue to profit from the

${ }^{143}$ Coffee, "Understanding Enron", supra note 8 at 7.

144 Ibid at 14.

145 Ibid at 8.

146 Ibid at 7. 
lucrative consulting contracts with Enron. ${ }^{147}$ In this example, we can clearly see the failure of the auditor as external gatekeeper, for neglecting to provide an accurate analysis that would show the material errors in Enron's financial disclosure. The key problem herein comes in the area of subgoal pursuit: that the interests of Arthur Andersen in its consulting role are not necessarily those of the shareholders and investors, and that this dysfunction of goal-oriented pursuit can lead to problems of conflict of interest on the part of the auditor. ${ }^{148}$

The senior corporate executives of Enron were held both criminally and civilly liable for the fraud. ${ }^{149}$ Charges were also brought against the accountants, Arthur Andersen, and an external law firm that had also worked on the scheme to manipulate the corporation's financial statements. The defence argument utilized by the V\&E law firm was that they were representing their client, and were thus bound by lawyer-client privilege. ${ }^{150}$ Andersen Accounting also had their own in-house and external lawyers that were working in conjunction with their accounting and auditor teams to facilitate the Enron financial schemes. ${ }^{151}$ Moreover, as both the auditing and consulting firm for Enron, Andersen was not able to rely on a defense of confidentiality and client privilege, since auditors are expected to have greater independence from their client by virtue of their role as external verifiers of

${ }^{147}$ John C Coffee Jr., "Gatekeeper Failure and Reform: the Challenge of Fashioning Relevant Reforms" (2004) 84 B. U. L. Rev. 301 at 318 [Coffee, "Gatekeeper Failure and Reform"] .

${ }^{148}$ Coffee, "Gatekeepers", supra note 7 at 24.

149 Ibid at 15-16.

150 Roger C Cramton "Enron and the Corporate Lawyer: A Primer on Legal and Ethical Issues" (2002) 58 Bus Law 143 at 162.

151 Ibid at 160. 
accounting information. This reasoning can help explain why Andersen was charged more heavily by the SEC than the law firm that was also involved in designing the transactions that resulted in debts being left off the balance sheet, because Andersen's role as an informational intermediary, through its role in certifying the financial statements, was more central to the planning and execution of the fraudulent scheme, than the law firm that simply provided legal consultation services with less emphasis on securities law disclosure. ${ }^{152}$

It is useful to consider the failure of Enron's internal gatekeepers, as well: that of the in-house lawyers and General Counsel who permitted, engineered, and benefitted from Enron's fraudulent operations. The SEC brought a civil action against the two senior lawyers working with Enron. Jordan Mintz was General Counsel of Enron, while Rogers was a senior securities and securities disclosure counsel in the position of Vice President of Tax and Tax Restructuring, a top position involving securities and disclosure law. This case was brought under the Securities and Exchange Act, and was thus a matter of securities fraud. ${ }^{153}$ One of the central allegations made by the SEC in this case was that these two lawyers were aware of the aggressive accounting schemes that were being utilized by Enron, and that their failure to discontinue contributing to such schemes meant that they were liable, by association, for securities fraud. ${ }^{154}$ While this particular case did not go to trial,

\footnotetext{
152 Ibid at 165.

153 United States Securities and Exchange Commission v Jordan H Mintz and Rex $R$ Rogers (SD Texas 2007), online: http://www.sec.gov/litigation/complaints/2007/comp20058.pdf at 5. 154 Ibid at 3.
} 
there was an out-of-court settlement between these two lawyers and the SEC. Both lawyers paid $\$ 25,000$ in civil fines, and $\$ 1$ disgorgement, and were barred from securities-related practice for two years. ${ }^{155}$

The Enron case is an instance where the corporate lawyers, accountants, and management were all seen to have contributed to the overall Enron fraud. ${ }^{156}$ Latent within this case we can see a conflict between different conceptions of the role of inhouse corporate counsel. Seen from a narrowly contractual view of the lawyer-client relationship it is possible to ask whether Mintz and Rogers had done anything wrong at all, as they were "simply" acting as transaction engineers following the orders of senior executive officers. However, a significant shift in regulatory approach by the SEC can be seen in this particular case, towards a wider interpretation of the responsibilities of corporate and securities lawyers. The model of accountability adopted by the SEC was that these two lawyers were seen as reputational intermediaries between the corporation and the markets, due to their facilitation of tax restructuring schemes that had a very significant impact on representations made by the corporation, to the securities markets. ${ }^{157}$

\footnotetext{
155 US Securities and Exchange Commission. Litigation Release No. 20866, "SEC Settles Civil Fraud Charges Against Two Former Enron In-House Attorneys" (January 26, 2009), online: $<$ http://www.sec.gov/litigation/litreleases/2009/lr20866.htm>. 156 Coffee, "Gatekeepers" supra note 7 at 30-32.

157 United States Securities and Exchange Commission v Jordan H Mintz and Rex R Rogers (SD Texas 2007), online: http://www.sec.gov/litigation/complaints/2007/comp20058.pdf at paras 87-90.
} 
It is in this case, and this application of the roles and responsibilities of the corporate and securities lawyer, that we can see the formulation of the in-house lawyer as a gatekeeper. This "gatekeeper" model enables us to see how the expert skills and knowledge that such lawyers possess were integral for the completion of Enron's fraudulent scheme. The in-house counsel plays a crucial enabling role because of their expertise in securities and disclosure law, as well as their ability to work closely with executive officers on a regular basis. Most critical for the understanding of professional gatekeeper liability is that the lawyers were held accountable, not as primary actors in the fraud. Rather, these professionals were deemed to be accountable on a secondary party basis, as intermediaries who created, perpetuated, and promoted specific strategies that had the effect of misleading the investor public and securities commissions..$^{158}$

At the same time, we can see that the role of external reputational intermediaries, such as accountants, is linked to the role played by the corporation's internal informational intermediaries, in that their ability to certify the quality of financial disclosure made to the investor public is in part contingent on the internal professionals providing accurate information. Should the internal executives sign off on financial disclosures that are misleading, the external auditors can be misled, as shown by the case of Enron and Livent, until it is too late and the investors have

158 US Securities and Exchange Commission. Litigation Release No. 20866, "SEC Settles Civil Fraud Charges Against Two Former Enron In-House Attorneys" (January 26, 2009), online: http://www.sec.gov/litigation/litreleases/2009/lr20866.htm. The wording of the SEC is relevant here, where Mintz and Rogers were said to have been "aiding and abetting" and having "contributed" to the Enron fraud. 
significantly lost their investments, and confidence, in the markets. Auditors may be unable to see through large amounts of data and perfectly see misleading schemes utilized by corporations..$^{159}$

The Enron case was widely seen as one of the turning-points in American securities law, representing a shift away from a self-regulatory approach to corporate governance, towards a more activist role for government regulation. 160 The Sarbanes-Oxley reforms that were brought about following the "Enron era" were designed to promote investor confidence and address issues that were seen to undermine the interests of the securities markets, notably, integrity of information disclosure and the need for more regulatory standards governing the responsibilities of both internal and external corporate gatekeepers. ${ }^{161}$ We will come back to the issues raised by these legislative reforms in the last chapter, after looking at two further case studies of gatekeeper failure.

\section{Hollinger Inc.}

In the context of the development of the role of the lawyer as internal gatekeeper within the corporation, the case of Hollinger international is also worth examining. Hollinger International, and its subsidiary Hollinger Inc., were part of a series of corporations that owned newspapers in Canada and the United States ${ }^{159}$ Langevoort, "Behavioural Economics of Corporate Compliance", supra note 27 at 93.

160 Bratton, supra note 112 at 1282.

161 Simmons \& Dinnage, supra note 5 at 104, 139-140. 
through a complex shareholding structure ultimately controlled by the corporation's chief executives. Hollinger International had offices in the United States, and Hollinger Inc. had offices in Toronto, Ontario. Ravelston was a holding corporation that was $98.5 \%$ controlled by the Hollinger executives. ${ }^{162}$ Conrad Black was the Chief Executive Officer of Hollinger Inc., Hollinger International, and Ravelston Corporation. John A. Boultbee was a professional accountant and Chief Financial Officer of Hollinger International. Peter Atkinson was Vice President and General Counsel of Hollinger Inc. Mark Kipnis was the General Counsel and Secretary of Hollinger International. ${ }^{163}$

All four Hollinger executives were charged with fraud for having:

"devised, intended to devise, and participated in a scheme to defraud [Hollinger] International and International's public shareholders of money, property, and their intangible right of honest services, to defraud the Canadian tax authorities of tax revenue, and to obtain money and property from these victims by means of materially false and fraudulent pretenses, representations, promises and omissions". 164

162 USA v Conrad M Black, John A Boultbee, Peter Y Jackson, Mark S Kipnis and The Ravelston Corporation Limited, No. 05 CR 727 (ND Ill 2005) at page 2 [USA v Black]. 163 Ibid at pages 3-5.

164 Ibid at page 9. 
Three of these executives were trained lawyers and one was a trained accountant. 165 Kipnis was the lowest level executive charged with fraud, in his position as general Counsel of Hollinger. It was Kipnis who drew up the non-competition agreement by which $\$ 5.5$ million in non-competition fees was paid to the other defendants on the sale of one of the corporation's newspapers, acting in his capacity as a 'transaction engineer' following instructions from senior corporate executives. ${ }^{166} \mathrm{He}$ argued that he was placed under pressure by the other executives to participate in the unauthorized scheme, and that he ought not to be charged because he did not derive any profit from the transactions, which involved the diversion of non-competition fees realized on the sale of the corporation's newspapers to companies such as Ravelston controlled by the corporation's executives, without the knowledge of, or approval by, the corporation's audit committee or board of directors. In the end, Kipnis was convicted for his role in the fraud and sentenced to probation with 6 months of home detention. ${ }^{167}$

\section{A failure of agency}

Within the context of models of good corporate governance it is clearly possible to see this case as a as an instance of deterioration of the principal-agency relationship. The principal in this case can be conceptualized as the Hollinger group of corporations, and the various investors that own shares in these publicly listed

165 Ibid at pages 3, 61.

166 Ibid at page 21.

${ }^{167}$ USA v Black on Appeal, supra note 2 at page 1. 
corporations. Part of the legal case against Black was that he had violated his fiduciary duty to the corporation by utilizing a scheme to defraud the company. Of critical interest was whether it was the actual receiving of non-competition fees that had been fraudulent, or whether it was the process that was flawed. The Court of Appeal found that the scheme was fraudulent: regardless of whether or not the executives deserved to have bonuses in their name, the process was contrary to American corporate governance policy. ${ }^{168}$ One way of providing a check to ensure that the executive officers were not violating their fiduciary duties to the corporation through the payment of non-competition fees was to have the transaction approved by the corporation's audit committee or the board of directors. The Court ruled that the managers specifically did not go to the Board because they knew that such a scheme would not be authorized, as it deprives the Hollinger corporation of financial capital that was wrongfully diverted to Ravelston corporation. 169

168 Ibid at 3. Part of the argument made by Black, et al. was that "The defendants do not argue that they were trying to defraud Canada; they argue that their recharacterization of management fees as compensation for granting covenants not to compete was proper under Canadian tax law, even if the receipt of such payments violated American law. Canada, they contend in effect, was willing to 'pay' the defendants in the form of a tax benefit in order to advance Canadian policy." 169 USA v Black on Appeal, supra note 2 at page 2. The judges found that "[n] either Hollinger's audit committee, which was required to approve transactions between Hollinger's executives and the company or its subsidiaries because of conflict-of-interest concerns, nor Hollinger's board of directors, was informed of this transaction." 
Internal gatekeeper liability and the "ostrich" theory of negligence

It is important to take into account how Kipnis as General Counsel was held accountable for his role in the Hollinger scheme. The court found that he knew, or had reasonable grounds for suspecting that there was corporate misconduct occurring, but willfully chose to ignore it and "bury his head" like an Ostrich. ${ }^{170}$ To elaborate, Justices Easterbrook and Posner held that, "[t]he jury was entitled to infer that Kipnis suspected a fraud, which he facilitated by his preparation of the agreement, but asked no questions lest his suspicion rise to a certainty."171 Kipnis' failure was thus where, having known or had a reasonable intimation of the possibility of corporate misconduct, he ought to have investigated further, as part of his mandate as in-house corporate counsel for Hollinger International. ${ }^{172}$

The view held by the U.S. trial court and court of appeal was that Kipnis should have performed his gatekeeping function of providing oversight of enterprise risk within Hollinger and reporting to the board. To choose to ignore the presence of misconduct is a clear violation of the corporate interest, and his failure to report up the corporate ladder to the Board of Directors and Audit Committee is

170 Ibid at pp. 13-16.

171 Ibid at 15-16.

172 Ibid at 15-16. 
tantamount to aiding and abetting the corporate fraud scheme of Conrad Black and the other executives. ${ }^{173}$

To situate this issue within the framework of agency theory, the General Counsel is deemed to have a principal-agent relationship with the corporation, and that there is an obligation for the General Counsel to act in the best interests of the corporation, even when the executive officers of the corporation are acting in a way that is prejudicial to the corporation's interests. Seen from the perspective of gatekeeping theory, by failing to raise red flags about the possibility of misappropriation of corporate funds, Kipnis lent his reputational capital as the senior legal professional within the corporation to the activities of the corporation's senior executives, and thus should be held accountable for his role in facilitating the financial scheme even though he did not personally benefit from it. ${ }^{174}$

As an internal professional gatekeeper Kipnis was not one of the beneficiaries of the fraud, but rather, his function was that of a transaction engineer who was utilized to create the scheme, and implicitly certify it through his position as general counsel. ${ }^{175}$ Kipnis was privy to the financial agreements that were central to the execution of the scheme that misappropriated funds in such a way that disclosure was not made to the Audit Committee that is a part of the Board of

${ }^{173}$ USA v Black on Appeal, supra note 2 at 15-16.

174 Ibid at 15.

175 Ibid at 4. 
Directors. ${ }^{176}$ As such, his failure to report to the board enabled the aforementioned managers, Boultbee, Black and Atkinson to abuse their position of authority in the corporation as a means of misappropriating funds for their personal benefit. ${ }^{177}$

One of the concerns related to this emergent role of the in-house lawyer as gatekeeper is that of lawyer-client privilege, and whether the expanded ethical obligations of the legal professional to investors as well as to the board of directors might involve any breach of confidentiality on the lawyer's part. In the Hollinger case, the court adopted the inn-keeper model of the in-house counsel's role, whereby the lawyer has a duty to give wise counsel to the board, and act as an information intermediary between the senior management and the board of directors, all in accordance with expected fiduciary obligations as General Counsel. ${ }^{178}$ Likewise, the collapse of Enron has shown that the over-emphasis on short-term profit and the use of overly aggressive accounting practices by professionals both internal and external to the corporation can lead to bankruptcy and significant harm to the investor public. ${ }^{179}$ One of the contributing factors to the failure to foresee the Enron collapse, was that the professionals involved in the transactions, from auditing, consulting, to legal services, were too closely aligned

\footnotetext{
176 Ibid at pages 2-3.

177 Ibid at 8-9.

178 USA v Black on Appeal, supra note 2 at page 4. The Court found that "as [Hollinger] International's in-house attorney, KIPNIS had a fiduciary duty of undivided loyalty to International, which among other things, required KIPNIS to disclose all material facts regarding all related party transactions to International's Audit Committee, and to refrain from assisting others in any breach of fiduciary duty against International."

179 Bratton, supra note 112 at 1326.
} 
with senior management, and failed to use their independent professional judgement to assess legal and financial risks affecting the corporation and its investors.

\section{Livent and the Ethical Responsbilities of Internal Corporate professionals}

The case of Livent is a fascinating one as it shows the relevance of how internal professionals, in this case, trained accountants, can be intimidated into failing to disclose financial irregularities in the corporation's financial statements, even when they are aware of their own professional responsibility to do so. As we have seen the theory of professional gatekeepers as reputational intermediaries is partly based on the assumption that the risk of loss of reputational capital by the professional is likely to provide a greater incentive to report wrongdoing, than the benefits to be gained through participation in the fraud. ${ }^{180}$ In this case the professional gatekeeper did eventually report the suspected financial irregularities, but not until the situation had changed such that it was likely the fraud was going to be exposed when an outside investor hired an external auditor to do a financial audit of the corporation's accounts.

Livent was a very successful entertainment company set up by Garth Drabinsky and Myron Gottleib, which held the production rights to large scale musicals and shows, like Phantom of the Opera and Ragtime. The corporate

${ }^{180}$ Coffee, "Understanding Enron", supra note 8 at 6. 
executives who founded the company wanted to turn Livent into one of the largest entertainment companies in North America, and were seeking outside investors to provide the corporation with more capital. ${ }^{181}$ The corporate executives had a strong incentive to show that the corporation was profitable, and to this end engaged in a complex scheme to hide expenses and overstate revenues, in order to ensure their continued access to capital markets. Following a forensic investigation into the company's accounts, ${ }^{182}$ the two executives were charged with fraud and sentenced to 5 and 7 years in prison. ${ }^{183}$ The corporation's vice president of finance and administration, Gordon Eckstein, plead guilty to the U.S. Securities and Exchange Commission for securities fraud, as he was a financial executive responsible for having instituted fraudulent schemes that were undetected by the audit committee and approved by the board. Ontario Securities Commission charges are still pending investigations. ${ }^{184}$ More recently, The Law Society of Upper Canada has begun examining whether the finding of fraud associated with Garth Drabinsky's involvement in the Livent scandal was such that would be "unbecoming" of a lawyer. ${ }^{185}$ It is valuable to take a closer look at the Chief Financial Officer of Livent,

${ }^{181} R$ v Drabinsky, supra note 3 at paras 17-25.

182 Ibid at para 35.

183 Ibid at para 189.

184 Janet McFarland, “OSC revives case against Livent executives” (February 21, 2013), online: Globe and Mail < http://www.theglobeandmail.com/report-onbusiness/industry-news/the-law-page/osc-revives-case-against-liventexecutives/article8952231/>.

185 The Canadian Press, "Livent co-founder Garth Drabinsky threatened with loss of lawyer's licence" (May 22, 2013), online: The Toronto Star <http://www.thestar.com/entertainment/2013/05/22/livent cofounder garth dra binsky threatened with loss of lawyers licence.html $>$. 
as her role was under significant scrutiny both in the court trial, as well as under professional regulation by the Chartered Accountants association of Ontario.

Additionally, the Chief Financial Officer of Livent, Maria Messina, was charged found guilty of two charges under the rules of professional conduct of the Institute of Chartered Accountants of Ontario, and fined \$7,500 and suspended from practicing as an accountant in Ontario for two years for her role in having undermined the public interest through her association with the Livent fraud.186 Maria Messina was formerly working with the accounting firm Deloitte and Touche, and provided auditing and consulting services to Livent. ${ }^{187}$ As she continued such a business relationship, she eventually developed a close relationship with Livent management and was brought in-house to the position of the Chief Financial Officer. ${ }^{188}$ In this position Messina provided internal auditing oversight of Livent's finances, and was responsible for consolidating the financial reports that were subsequently an integral part of the Livent fraud.

The failure of the internal oversight of Livent clearly shows how fraudulent executives can look to obtain reputational legitimacy by hiring professionals inhouse, and that this legitimacy can in turn enable the corporate executives to manipulate internal and external oversight that has been explicitly designed to

186 Institute of Chartered Accountants for Ontario, Discipline Committee re Maria Bernedette Messina, (Case Document) (Toronto: Institute for Chartered Accountants for Ontario, 2000). ${ }_{187} R v$ Drabinsky, supra note 3 at para 63.

188 Ibid at para 66. 
provide greater informational disclosure as to the full and true nature of a corporation's status and conditions to the securities markets. ${ }^{189}$ Messina's professional expertise as an auditor provided Livent executive management with the necessary skills and expert knowledge to be able to manipulate financial reports in such a way that would not be detected by internal ${ }^{190}$ and external audits that were designed to detect material financial errors and misstatements. ${ }^{191}$

In this case, Messina failed to act as a gatekeeper because she blindly acquiesced to executive management's fraudulent scheme, and continued to facilitate earnings disclosure statements that were, according to Justice Benotto, an "intentional misstatement of the company's true financial situation", thus in violation of securities disclosure law. ${ }^{192}$ Messina's role was far too much as a transaction engineer that facilitated a financial scheme without raising "red flags" about the fraudulent and misleading nature of such statements disclosed to the securities markets. She was only willing to become a whistleblower and raise awareness of the fraudulent executive practices at Livent when she realized that there was no other way for the fraud to be hidden. Thus, her disclosure was motivated by self-preservation rather than by a sense of professional responsbility. She had an incentive to disclose at this point, so as to ensure that she would not be charged.

189 Ibid at para 509.

190 Ibid at para 78.

191 Ibid at para 75.

192 Ibid at para 509-510. 
The Livent scheme, similar to Enron, ${ }^{193}$ was seen as being the result of a pervasive corporate culture that "was characterized by threats, intimidation, abusive and demeaning language, and other workplace abuse, which generated an atmosphere of fear and precluded disagreement with senior management". 194 This culture was driven by a desire for an aggressive pursuit of profit, driven by certain members of the executive. The professionals did not appear to be the central actors who initiated the manipulation of the corporation's accounts. However, it was with their contributions that such frauds were allowed to occur. This is shown by how the judge found that "she was paid to do as she was told; she was not paid to think."195

The role of Maria Messina can be seen to be an "ostrich", similar to the General Counsel Kipnis in Hollinger. ${ }^{196}$ Maria Messina similarly failed in her role as an executive officer because her failure to notify the Board of Directors Audit Committee of the fraudulent statements that were being provided to them, as well as the external auditors, was in clear violation of her fiduciary obligations as an executive officer. Moreover, she was in violation of her professional responsibilities as an accountant, insofar as her contributions to the Livent fraud harmed the public interest. It is for this reason that Messina was subsequently charged, fined, and

193 Langevoort, "Hyper-Competition”, supra note 96 at 973.

194 Institute of Chartered Accountants for Ontario, supra note 187 at 12.

$195 R$ v Drabinsky, supra note 3 at paras 70, 89.

196 USA v Black on Appeal, supra note 2 at pages 15-16. 
suspended from the Institute of Charted Accountants in Ontario ${ }^{197}$ for having failed in her professional ethical responsibilities to the public.

Thus, it seems evident that there needs to be a greater emphasis placed on the professional ethical responsibilities of in-house corporate counsel and accountants for there to be a change in the internal corporate culture that professionals are willing to acquiesce to. ${ }^{198}$ In particular it seems crucial for Canadian securities and corporate law to provide a means whereby there are less incentives for professionals to keep silent about fraudulent or problematic practices within the corporation. An obligation to report up, or provide a noisy withdrawal, would first require the professional to report up the ladder of authority within the corporation, in hopes that such reporting would provide an adequate internal response to suspected unlawful behaviour by an internal compliance officer or the Board of Directors. In the cases of Livent ${ }^{199}$ and Hollinger, ${ }^{200}$ the corporation's audit committee and the Board of Directors were not aware of the misstatements that were occurring at the behest of the corporate executives. Thus, ideally, an internal response by corporate management would provide a means whereby corporate reputation can be potentially maintained, while still enforcing the confidentiality and privilege that exists between the corporation and their officers and

197 Institute of Chartered Accountants for Ontario, supra note 187 at 9.

198 Langevoort, “Getting (Too) Comfortable”, supra note 6 at 7.

${ }^{199} R$ v Drabinsky, supra note 3 at para 97.

200 USA v Conrad M Black, Peter Y Jackson, John A Boultbee, \& Mark S Kipnis, No. 074080 (7th $\operatorname{Cir} 2008$ ) at page 8. 
professionals. $^{201}$ Should the internal corporate culture not be remedied by management, then an obligation would exist to disclose such information to an external agency such as the Securities Commission or a professional association, which could respond by conducting an external intervention so as to avoid harm to the investor public. Thus such professionals would fulfill their role as a gatekeeper by withholding their services from "wrongdoers". This would thus provide a critical means whereby the reputational capital of professionals would be deprived from such wrongdoers, as the services of a lawyer and accountant are essential for access to the capital markets. ${ }^{202}$

Previous case studies have shown that there are reputational factors that influence the confidence of investors with respect to the reliability of the information disclosed by the corporation, to the markets at large. Where such information is unreliable, the relevant pricing of a corporation's shares can be inaccurate, thus potentially leading to further economic harm to investors, ${ }^{203}$ and the significant reductions in the financial valuation of the corporation's assets. ${ }^{204}$ Thus, we can see the importance for professionals working within a corporation to act not just as transactional engineers in pursuit of management's goals, but to take into account a wider corporate interest that extends beyond the immediate concerns of management, so as to provide a means of providing a check and balance

201 Cramton, "Enron and the Corporate Lawyer", supra note 150 at pages 157-159.

202 Kraakman, "Gatekeepers", supra note 10 at 69.

203 Coffee, "Gatekeepers", supra note 7 at 32.

${ }^{204}$ Donald C Langevoort, “Organized Illusions: A Behavioural Theory of Why Corporations Mislead Stock Market Investors (And Cause Other Social Harms)" (1997) 146 U Pa L Rev 101 at 127-28. 
on incentives for corporate executives to manage a corporation in such a way that can harm the stability and continued success of a corporation. Put differently, the agency relationship between the agents of a corporation, such as executives, lawyers, accountants, all of whom represent the interests of a corporation as principal, can better represent the interests of the corporate principal by taking into account the inherent risks that are present for short-term profit, over-aggressive growth, wrongful disclosure to or defrauding the investor public that can harm the very interests of the corporate principal they are expected to represent.

A significant contribution that the gatekeeper model provides is that it situates the agency relationship that exists between the corporation and the professional as existing within the context of a wider securities market that is ultimately reliant on the quality of information that is made available through such professional intermediaries. ${ }^{205}$ The cases of Livent, Hollinger, and Enron have shown that the professionals within such corporations are at risk of being unable to fulfill their roles in support of their fiduciary obligations that such executives have pertaining to the interests of the corporation as principal, especially where such a corporation's interests are pertaining to longer-term stability, growth, and maintenance of reputational capital. The failure of such professionals to raise concerns that can be reasonably foreseen to have a detrimental impact to the long term interests of their corporate client can be seen, according to agency theory, as a

205 Kraakman "Gatekeepers", supra note 9 at 82 shows an example of such an obligation under securities law is seen where "gatekeepers must affirmatively prove that they conducted a 'reasonable investigation' of the issuer's representationsconventionally termed 'doing due diligence' - on behalf of prospective investors." 
clear deterioration and cost that can fundamentally affect the well-being of the corporate-professional relationship. ${ }^{206}$

${ }^{206}$ Lyman, supra note 95 at 1108-1109. 


\section{Chapter 4: Concluding the Debate}

Having examined gatekeeper models and their application to the role of the general counsel within the structure of corporate governance, and implications within the securities markets, it is valuable to consider whether too much is being asked of lawyers. As the Law Society of Upper Canada observed, in its response to the proposed Sarbanes-Oxley reforms imposing a more stringent gatekeeper responsibility on legal counsel practicing securities law in the United States, the lawyer's duty to respect the confidentiality of any information disclosed by the client plays a crucial role in maintaining the integrity of the lawyer-client relationship. Placing a positive obligation on legal counsel to report any suspected breaches of fiduciary duty or violations of law to an outside agency such as a securities commission, as proposed under the SEC rules of professional conduct for attorneys practicing before the securities commission risks placing legal counsel representing corporations into a difficult position where they are forced to choose between preserving client confidentiality and their duty to disclose..$^{207}$

A lawyer, is, after all, expected to be a zealous advocate for their client. The legal system expects such dedication, that the lawyer as advocate would "raise fearlessly every issue, advance every argument, and ask every question, however

\footnotetext{
${ }^{207}$ Letter from Law Society of Upper Canada to U.S. Securities and Exchange Commission (6 December 2002) online Re: The Law Society's Submission On The Proposed Rule: Implementation Of Standards of Professional Conduct for Attorneys, Securities and Exchange Commission, online: http://www.sec.gov/rules/proposed/s74502/vkrishna1.htm at "The Requirement for a 'Noisy Withdrawal'” section ["Letter from Law Society of Upper Canada”].
} 
distasteful". The best way of guaranteeing the independence of the lawyer-client relationship is by ensuring that there is effective communication and confidentiality between the lawyer and their client, so that the client would not feel like there could be the potential that the information disclosed to their lawyer as representative could be utilized against them at a future time. Imposing a positive obligation on the lawyer to disclose confidential information to an outside agency would thus place the lawyer in conflict with the law society's rules of professional conduct, which require the lawyer to preserve the confidentiality of all information regarding the business and affairs of the client. ${ }^{208}$

This potential conflict may be slightly more complex for the position of the general counsel, who while trained as a lawyer, may not be actively practicing at the bar, and thus would arguably not be subject to the rules of professional conduct while acting in their capacity as general counsel. At the same time, the strategic location of the general counsel as a professional intermediary who also functions as an executive officer of the corporation, and has access to important, and highly sensitive corporate information, makes the role of the general counsel crucial to the debate over the gatekeeper responsibilities of corporate professionals as information intermediaries.

In order to facilitate an understanding of the role that the general counsel has within the corporation, transaction engineer and gatekeeper models have been

${ }^{208}$ Ibid. 
respectively examined in order to more clearly understand what the implications of their role can be. To recapitulate, the role of the transaction engineer provides a means of seeing that the general counsel is focused predominantly on the facilitation of business transactions, and secondarily focused on fiduciary issues and legal oversight. From this perspective, the general counsel is seen as a business executive that can be called upon to utilize their legal skills and abilities to facilitate business transactions, such as the drafting of contracts and planning of complex matters that can have significant legal implications and value-creation for the corporation, such as mergers and acquisitions. ${ }^{209}$ From this perspective, the responsibility of the General Counsel becomes value maximization through the facilitation of corporate transactions, and there can be incentives for the general counsel to provide creative and potentially risky legal strategies in the pursuit of such transactions so as to provide greater competitive advantage for the corporation. ${ }^{210}$ A concern arises when such a pursuit of profit and competitive advantage may conflict with the ethical responsibilities of corporate counsel and undermine the fiduciary responsibility that the general counsel owes towards the corporation and its shareholders.

The case studies of Enron, Livent, and Hollinger have shown how the model of the general counsel as a transaction engineer can result in infringements on the fiduciary and ethical responsibilities of the General Counsel as both a lawyer, and a corporate executive. Each of these case studies involved a failure of corporate

209 Simmons \& Dinnage, "Innkeepers", supra note 5 at 115.

${ }^{210}$ Cramton, "Enron and the Corporate Lawyer", supra note 150 at 165. 
governance in which professionals such as lawyers and accountants were lulled into a sense of complacency and would acquiesce to creative and aggressive forms of corporate transactions promoted by senior corporate management. Alternatively, these very professionals would take part as "loophole engineers" whose task was to exploit perceived loopholes in regulatory enforcement standards in pursuit of increased profit for the corporation, ${ }^{211}$ or through lucrative consulting transactions, such as the role of Arthur Anderson in the Enron case study, often in ways that conflicted with the role that the auditors had traditionally played as professional gatekeepers.

The Rules of Professional Conduct of the Law Society of Upper Canada recognize the difficult position that a lawyer working within a corporation may face when they become aware of any breach of fiduciary duty or illegal or fraudulent act on the part of the corporation or any of its officers. In such a case the lawyer should not knowingly participate in the illegal or fraudulent conduct, or the breach of fiduciary duty. ${ }^{212}$ But at the same time it is not clear what the in-house lawyer's duty is with respect to acting on the information about the illegal or fraudulent behavior. The commentary to the Rules of Professional Conduct, approved by the Law Society in 2000, states that as a general rule that the lawyer, even when knowing of misconduct or illegal behavior on the corporation's part, should keep such client

211 Richard W Painter "Transaction cost engineers, loophole engineers or gatekeepers: the role of business lawyers after the financial meltdown" Claire A Hill \& Brett H McDonnell eds, Research handbook on the Economics of Corporate Law (Edward Elgar: UK, 2012) at 261.

212 The Law Society of Upper Canada, Code of Professional Conduct, Toronto: Law Society of Upper Canada, 2000, Rule 2.02(1.1). 
information strictly confidential, and, with very few exceptions, such as involving risk of death or serious bodily harm, not report it to authorities outside the corporation. ${ }^{213}$

The commentary to the rules does suggest that the there are some steps the lawyer should take when in possession of information about illegality or breach of fiduciary duty within the corporation. This involves reporting the information up the ladder of authority within the corporation, so that an internal investigation can be made into the suspected misconduct. If no appropriate action is taken by the organization, the commentary suggests that it may be appropriate for the lawyer to resign, or to withdraw his or her professional services from the client. ${ }^{214}$ But there is no provision for noisy withdrawal, through reporting the reasons for the withdrawal of professional services to any external agency, such as the securities commission or the law society. To do so, would place legal counsel in the position of having breached the duty of confidentiality towards the client.

Additionally, it is possible that in-house corporate counsel facing an ethical dilemma about reporting a suspected breach of fiduciary duty or financial misrepresentation could face retaliation or a loss of professional employment opportunities if they are perceived as "not being a team player", and "breaking the code" of confidentiality within corporate management. An in house corporate counsel "noisily" withdrawing their services from a corporation under such

213 "Letter from Law Society of Upper Canada", supra note 208.

214 "Letter from Law Society of Upper Canada", supra note 208. 
circumstances might find it difficult to obtain employment as an in-house corporate counsel with other potential corporate employers. This concern may also operate as a behavioural condition that influences the lawyer's decision to report up or report out under such circumstances. Regulatory mechanisms would have to take these concerns into account. One possibility could be having a specialized, confidential oversight board that can serve as a point of information transfer between the General Counsel and an external organization that is affiliated with, but arms length from, the Securities Commission. An example of this is the Public Company Accounting Oversight Board in the United States, which was instituted through the Sarbanes-Oxley Act to investigate and discipline "firms and persons associated with firms for noncompliance."215 All such investigations and communications between the Board and the persons that are before it are strictly confidential, thus addressing the concern that those disclosing information about misleading corporate financial information could be subject to retaliatory sanctions.

At present, however, the rules of professional conduct still emphasize client confidentiality over the duty to disclose. A lawyer acting on behalf of a corporation cannot act as a 'whistle blower', without risking being in breach of their professional responsibilities to the corporation as client. Theoretically, the legal counsel could even be subject to disciplinary charges for breach of confidentiality under the Law Society rules. Arguably, this emphasis on protecting client confidentiality tends to promote passive acquiescence on the part of legal professionals, when they are 215 Public Company Accounting Oversight Board. "Enforcement" section, online: http://pcaobus.org/Enforcement/Pages/default.aspx. 
aware of any suspected fraud or misconduct on the part of management, rather than promoting an active gatekeeping function. For the in-house counsel, it seems it is better to act as an ostrich than a 'whistle-blower'.

By contrast, the rules of professional conduct established under the U.S. Sarbanes-Oxley legislation do contain a provision for 'noisy withdrawal' on the part of corporate counsel when they are aware of fraudulent behavior within the corporation. The U.S. Sarbanes-Oxley reforms looked to provide heightened emphasis on the general counsel's responsibility as a gatekeeper. The goal was that there would be a clearly defined obligation for in-house counsel to report up the ladder of authority within the corporation, all the way to the board of directors if necessary, in cases where the general counsel is aware of instances of potential legal violations. Should this 'reporting up' obligation fail to address the problem, then counsel would have an option to withdraw their services, and notify the securities commission of the issues of concern $^{216}$ - the so-called 'noisy withdrawal' provisions. $^{217}$

It is important to note that the responsibility to report up the ladder of authority within the corporation already existed under the American Bar Association's model rules of professional conduct, as it does under the Law Society of Upper Canada's rules of professional practice.218 However, the regulatory

216 Sarbanes-Oxley Act of 2002, Pub L 107-204, 116 Stat 745, section 307.

217 Paton, supra note 96 at 549.

218 "Letter from Law Society of Upper Canada", supra note 208. 
changes concerning the noisy withdrawal provision were intended to reinforce the gatekeeping role the general counsel plays as an information or reputational intermediary, not only within the corporation, but also with respect to the integrity of the capital markets.

There was significant concern about the implication of these new provisions, as expressed in the response by the Law Society of Upper Canada to the proposed new rules of professional conduct for corporate legal counsel practicing in the field of securities law. A particular concern expressed by the Law Society was that the noisy withdrawal provisions would serve to undermine the principle of lawyer independence, by requiring a lawyer to publicly disclose to a government agency the reasons for their withdrawal of professional services to the corporate client. ${ }^{219}$ The Law Society was concerned that such an obligation would serve to significantly reduce the ability of a lawyer to represent their client, and secondly, could undermine the very reputation of a law professional as being a trusted source of legal advice and representation in the legal services market. ${ }^{220}$ Additionally, the provisions could potentially result in a situation in which a Canadian lawyer working for a corporation with its shares listed on the New York stock exchange, could be subject to two different sets of codes of professional conduct, which impose different standards of professional conduct on the lawyer. The law society's position was that Canadian lawyers should be exempted from this regulation and that the existing up the ladder reporting requirements were sufficient to satisfy the legal

219 Ibid.

220 Ibid at "A Final Statement" section. 
counsel's fiduciary obligations to the corporation, while preserving lawyer-client confidentiality. ${ }^{221} \mathrm{~A}$ further implication is that lawyers who are not "appearing and practicing" may be subject to Securities Commission review for conduct that they are not retained to advise on.

Despite criticism from various commentators, and from some state bar associations, the Securities and Exchange Commission implemented the SarbanesOxley reporting up and noisy withdrawal rules because it was considered there was a clear and pressing policy concern that justified an enhanced gatekeeping role for the in-house legal professional. The primary justification for such increased reporting up and noisy withdrawal obligations that were intended to supersede and go beyond the established Professional Rules of Conduct established by many Bar Associations was that the protection of investors was of significant concern both for the integrity of the markets, as well as continued flow of capital in response to corporate frauds and scandals such as Enron. ${ }^{222}$ As the investigation into the causes of the Enron collapse showed, professionals both inside, as well as outside, the corporation could be 'captured', and their independence manipulated so as to increase the appearance of legitimacy for corporate transactions and operations that would later be discovered as fraudulent. The Sarbanes-Oxley reforms were designed to address this concern and reduce the opportunity for such frauds to occur whereby the professionals within the corporation would have reduced incentives to acquiesce and support potentially fraudulent corporate transactions.

221 Ibid at "The Definition of 'Appearing and Practicing' Before the Commission". 222 Simmons \& Dinnage, supra note 5 at 104-05. 
The most fundamental issue in determining whether the General Counsel deserves to be the focus of securities law reform in the Canadian context is the question whether the general counsel, as a business executive who has legal expertise, should be required to play a more pro-active role as gatekeeper with responsibility for compliance issues affecting the corporation, in addition to their role as transaction engineer. The Sarbanes-0xley reforms with respect to the role of in house legal professional were based on the policy concern, in light of Enron, that a passive gatekeeping role for in house counsel is akin to promoting passive acquiescence. Something more needed to be done to promote a more active gatekeeping function, whereby in house corporate counsel are under a duty to act proactively to warn of their knowledge or suspicion of wrongdoing in the corporation, first internally within the existing corporate managerial and oversight structure; and if no response happens from within the corporation, to indicate their concerns to an outside agency, without being accused of or charged with professional misconduct.

The Sarbanes-Oxley reforms have attempted to redefine the role of the general counsel as a specialized corporate officer with an active role in internal corporate oversight. The general counsel, as a senior officer of the corporation, not only has access to much sensitive corporate information, but is also, through their training as a legal professional, uniquely positioned to be able to understand and foresee the legal implications of different aspects of the corporation's operations. As 
such, the general counsel is seen as having a crucial gatekeeping role as a reputational intermediary both within the corporation,,23 as well as beyond the corporation towards the investor public. ${ }^{224}$ This means that the general counsel has an obligation not only to promote the best interests of the corporation by acting as a transaction engineer, but also an ethical duty to ensure that the operations of the corporation are conducted in compliance with relevant legal and regulatory standards under securities legislation. The Sarbanes-Oxley legislative reforms have taken seriously the interests of the investor public by obliging the general counsel not only to report any knowledge of financial misstatements to the audit committee or the board of directors, but also, in appropriate circumstances, where the general counsel feels obliged to resign and withdraw their professional services, to also disclose information to the Securities Commission, so that the Securities Commission can intervene where necessary so as to protect the interests of the investor public and the integrity of the markets. Since investors are inherently dependent on the quality of financial information disclosed by corporations, the rules permitting legal counsel to make a 'noisy withdrawal' are intended to enable investors to be able to better protect their interests, and thus reduce the potentially

223 Coffee, "Gatekeepers", supra note 7 at 195. As Coffee elaborates, "the inside counsel is uniquely positioned to specialize in preventive law. The enhanced professional status of the in-house counsel depends to a considerable degree on accepting and promoting this responsibility, thereby staking out turf in the internal tug-of-war over authority and jurisdiction within the large public corporation."

${ }^{224}$ Ibid at 193-95. 
adverse impact that fraudulent corporate practices can have on the securities markets. ${ }^{225}$

The question then becomes whether the time has come to seriously reconsider the implications of the role of the general counsel as a transaction engineer, and consider imposing a more enhanced reporting up and noisy withdrawal requirement on the general counsel as a gatekeeper responsible to external stakeholders as well as to corporate management. This also involves a consideration of the role of the general counsel, and whether the general counsel can effectively avoid any ethical responsibility to act as an internal professional gatekeeper within the corporation as a consequence of their formal professional status as a 'non-practicing lawyer'. It has been argued that the general counsel is uniquely positioned to be able to perform a more active gatekeeping function, because of their access to information as senior corporate officers, and their professional legal knowledge as lawyers. In a sense, then, the general counsel can be seen as a person that can reduce potential agency costs by enabling a means of providing legal risk analysis and preventive lawyering. If the general counsel fails to ask question or to raise red flags when faced with information about possible internal corporate impropriety or misstatements of the corporation's financial statements, the effects are likely to be felt not just within the corporation, but also on wider stakeholder constituencies such as shareholders, employees and creditors. The case studies analyzed in this thesis regarding the Enron, Hollinger and Livent

225 Ibid at 212-13. 
frauds have provided ample evidence to show that similar risks of frauds and or financial misconduct have occurred in Canada, as well as in the United States, and that the passive acquiescence or active facilitation by internal professionals within the corporation was in each case a factor in enabling the financial misstatements or fraud to go undetected for so long. 


\section{Works Cited}

\section{【URISPRUDENCE}

BCE v 1976 Debentureholders, 2008 SCC 69, 3 SCR 560.

Conrad M Black, John A Boultbee, and Mark S. Kipnis v United States, 561 US 130

S Ct 2963.

In re Caremark Inc. Derivative Litigation 1996 Delaware Chancery 698 A.2d 959.

Peoples Department Stores, Inc v Wise, [2004] 3 SCR 461.

$R v$ Drabinsky, 242 CCC (3d) 449, 2009 CanLII 12802 (ON SC).

USA v Conrad M Black, John A Boultbee, Peter Y Jackson, Mark S Kipnis and The Ravelston Corporation Limited, No. 05 CR 727 (ND Ill 2005).

USA v Conrad M Black, Peter Y Jackson, John A Boultbee, \& Mark S Kipnis, No. 07-4080 (7th Cir 2008).

United States Securities and Exchange Commission v Jordan H Mintz and Rex R Rogers (SD Texas 2007), online: http://www.sec.gov/litigation/complaints/2007/comp20058.pdf.

\section{LEGISLATION}

Canada Business Corporations Act, RSC 1985, c. C-44.

Sarbanes-Oxley Act of 2002, Pub L 107-204, 116 Stat 745.

The Law Society of Upper Canada. Code of Professional Conduct, Toronto: Law Society of Upper Canada, 2000.

\section{SECONDARY MATERIALS: SCHOLARLY ARTICLES}

Bainbridge, "Caremark and Enterprise Risk Management"(2009) 34 J of Corp Law 968 at 975. Also see Geoffrey P. Miller "A Modest Proposal for Fixing Delaware's Broken Duty of Care" (2010) 1 Colum B L Rev 319.

Beasley, Mark S, Joseph V Carcello, Dana R Hermanson \& Terry L Neal. "The Audit Committee Oversight Process" (2009) 26 Contemp Account Res 65.

Ben-Ishai, Stephanie "Corporate Gatekeeper Liability in Canada" (2007) 42 Tex Int'l LJ 441.

Berle, Adolf A. and Gardiner C. Means The Modern Corporation and Private Property (New Jersey: Rutgers Transaction Publishers, 1932).

Bushman, Robert M. and Abbie J Smith "Transparency, Financial Accounting Information, and Corporate Governance" (2003) 9 Economic Policy Review 65

Bratton, William W. "Enron and the Dark Side of Shareholder Value" (2002) 76 Tul L Rev 1275.

Carle, Susan. "Theorizing Agency" (2005) 55 Am U LR 307.

Cramton, Roger C. "Enron and the Corporate Lawyer: A Primer on Legal and Ethical Issues" (2002-2003) 58 Bus Law 143.

Coffee Jr., John C. "Beyond the Shut-eyed Sentry: Toward a Theoretical View of Corporate Misconduct and an Effective Legal Response" (1977) 63 Va L R 1099. 
------. "Gatekeeper Failure and Reform: the Challenge of Fashioning Relevant Reforms" (2004) 84 B U L Rev 301.

------ Gatekeepers: The Professions and Corporate Governance (New York: Oxford University Press, 2006).

------. "The Acquiescent Gatekeeper: Reputational Intermediaries, Auditor Independence and the Governance of Accounting" (Working Paper) (New York, Columbia Law School, 2002), online: http://papers.ssrn.com/sol3/papers.cfm?abstract id=270944.

------ "The Attorney as Gatekeeper: an Agenda for the SEC" (2003) 103 Colum L Rev 1293.

------. Understanding Enron: 'It's about the Gatekepeers, Stupid' (Working Paper) (New York: Columbia Law School, 2002), online: http://mba.tuck.dartmouth.edu/mdm/AlumniLearningLinks/CoffeeOnEnron. pdf

------. "What Caused Enron?: A Capsule Social and Economic History of the 1990's" (2003) Columbia Law School Working Paper No. 214, accessed online http://papers.ssrn.com/sol3/papers.cfm?abstract id=373581.

Easterbrook, Frank H. "Contract and Fiduciary Duty" (1993) 36 J. L. \& Econ. 425

Fama, Eugene F. "Agency Problems and the Theory of the Firm" (1980) 88 J Polit Econ 288.

Hazard, Geoffrey C Jr. "Triangular Lawyer Relationships: An Exploratory Analysis" (1988) 68 BUL Rev 1.

Hackett, Susan. "Corporate Counsel and the Evolution of Practical Ethical Navigation: An Overview of the Changing Dynamics of Professional Responsibility in In-House Practice" (2012) 25 Geo J Legal Ethics 317.

Imhoff Jr., Eugene A. "Accounting Quality, Auditing and Corporate Governance" (2003) Accounting Horizons 117.

Kirkpatrick, Grant. "The Corporate Governance Lessons from the Financial Crisis" 2009 OECD Journal: Financial Market Trends 61.

Kraakman, Reinier H. "Gatekeepers: The Anatomy of a Third-Party Enforcement Strategy" (1986) 2 JL \& Econ 53.

Lan, Luh Luh \& Loizos Heracleous. "Rethinking Agency Theory: the View From Law" (2010) 35 Acad Manag Rev 294.

Langevoort, Donald C. "Chasing the Greased Pig down Wall Street: A Gatekeeper's Guide to the Psychology, Culture, and Ethics of Financial Risk Taking" (2011) 96 Cornell L Rev 1209.

------."The Behavioural Economics of Corporate Compliance with Law” (2002) 2002 Colum Bus L Rev 71.

------. "Getting (Too) Comfortable: In-House Lawyers, Enterprise Risk and the Financial Crisis (2012) Wis L Rev 495.

------. "The Organizational Psychology of Hyper-Competition: Corporate Irresponsibility and the Lessons of Enron" (2002) 70 Geo Wash L Rev 968.

------."Organized Illusions: A Behavioural Theory of Why Corporations Mislead Stock Market Investors (And Cause Other Social Harms)" (1997) 146 U Pa L Rev 101.

Laski, Harold. "The Early History of the Corporation” (1917) 30 Harv L R 561. 
Jensen, Michael C \& William H Meckling. "Theory of the Firm: Managerial Behavior, Agency Costs and Ownership Structure" (1976) 3 J Financ Econ 305.

Johnson, Lyman PQ. "Are Corporate Officers Advised About Fiduciary Duties" (2009) 64 Bus Law 1105.

Machen, Arthur M. “Corporate Personality” (1911) 24 Harv L R 253.

Painter, Richard W. "Transaction cost engineers, loophole engineers or gatekeepers: the role of business lawyers after the financial meltdown" in Claire A Hill \& Brett H McDonnell eds, Research handbook on the Economics of Corporate Law (Edward Elgar: UK, 2012).

Paton, Paul D. "Corporate Counsel as Corporate Conscience: Ethics and Integrity in the Post-Enron Era" (2006) 84 Can Bar Rev 533.

Puri, Poonam \& Stephanie Ben-Ishai. "Proportionate Liability Under the CBCA in the Context of Recent Corporate Governance Reform: Canadian Auditors in the Wrong Place at the Wrong Time?" (2003) 39 Can. Bus. L.J. 36

Raymond, Robert L. "The Genesis of the Corporation" (1906) 19 Harv Law Rev 350

Romano, Roberta. "The Shareholder Suit: Litigation without Foundation?" (1991) 7 JL Econ \& Org 55.

Rosenstein, Stuart \& Jeffrey G Watt, "Outside directors, board indepenendence, and shareholder wealth" (1990) 26 JFE 175.

Sarra, Janis. "Modernizing Disclosure in Canadian Securities Law: An Assessment of Recent Developments in Canada and Selected Jurisdictions" Commissioned by the Task Force to Modernize Securities Legislation in Canada (2006)

Shapiro, Susan P. "Agency Theory" (2005) 31 Annu Rev Sociol 263.

Simmons, Omari S \& James D Dinnage. "Innkeeepers: A Unifying Theory of the InHouse Counsel Role" (2011) 41 Seton Hall L Rev 76.

Watts, Ross L and Jerold L Zimmerman, "Agency Problems, Auditing, and the Theory of the Firm: Some Evidence" (1983) 26 JL \& Econ 613

Muller-Freienfels, Wolfram. "Law of Agency" (1957) 6 Am J Comp L 165

\section{SECONDARY MATERIAL: MEDIA ARTICLES}

Canadian Press, The. "Livent co-founder Garth Drabinsky threatened with loss of lawyer's licence" (May 22, 2013), online: The Toronto Star http://www.thestar.com/entertainment/2013/05/22/livent cofounder garth drabinsky threatened with loss of lawyers licence.html.

Institute of Chartered Accountants for Ontario, Discipline Committee re Maria Bernedette Messina, (Case Document) (Toronto: Institute for Chartered Accountants for Ontario, 2000).

McFarland, Janet. “OSC revives case against Livent executives” (February 21, 2013), online: Globe and Mail, online: http://www.theglobeandmail.com/report-onbusiness/industry-news/the-law-page/osc-revives-case-against-liventexecutives/article8952231/.

Public Company Accounting Oversight Board. "Enforcement" section, online: http://pcaobus.org/Enforcement/Pages/default.aspx.

US Securities and Exchange Commission. Litigation Release No. 20866, "SEC Settles Civil Fraud Charges Against Two Former Enron In-House Attorneys" (January 
26,

2009),

online:

http://www.sec.gov/litigation/litreleases/2009/lr20866.htm. 